\title{
Ecosystems of invasion and metastasis in mammary morphogenesis and cancer
}

\author{
MARC MAREEL*,1 and SUSANA CONSTANTINO ${ }^{2}$ \\ ${ }^{1}$ Department of Radiotherapy and Experimental Cancer Research, University Hospital Ghent, Belgium and ${ }^{2}$ Angiogenesis \\ Unit, Instituto de Medicina Molecular, Facultade de Medicina de Universidade de Lisboa, Lisbon, Portugal
}

\begin{abstract}
The present review describes molecular and cellular mechanisms of cancer invasion and metastasis as compared to mammary gland development considering communication inside and between ecosystems. At the level of the individual cell, invasion programs are written by an ecosystem of signalling pathways each of which steers several invasion-related cellular activities. At the supracellular level, communication within the epithelial compartment involves cells of the same origin, but with different phenotypes including stem cells. A similar interaction occurs between the various cells of the stromal compartment. Crucial for our understanding of tumor or mammary gland ecosystems are the mutual interactions between cells of the epithelial and cells of the stromal compartment. An update is provided for endothelial cells, cancer-associated fibroblasts and macrophages that are implicated in angiogenesis, desmoplasia and inflammation respectively. At the level of the organism, distant ecosystems, comprising primary tumor site, sites of metastasis, bone marrow and endocrine glands among others, are in continuous contact through circulating cells and soluble ligands. Our review suggests consideration of these ecosystems when designing therapeutic strategies.
\end{abstract}

KEY WORDS: invasion, metastasis, ecosystem, molecular communication, cancer therapy

\section{Introduction}

Embryologists and oncologists are interested in each others domains because the molecular pathways, cellular activities and pathways that regulate development and cancer are similar, yet display subtile differences (Hodges and Rowlatt, 1994). Both cancer cells and embryonic cells express a plastic, multipotent phenotype. Embryonic development implicates cell proliferation and spatial reorganisation of cell populations creating typical organ- and tissue-specific phenotypes to the benefit of the organism. Tumor development implicates similar activities creating a "distorted but recognizable caricature of the tissue from which they are derived", yet resulting in the destruction of the organism (Tarin, 2006).

Molecules expressed during embryogenesis and downregulated in adult tissue are re-expressed in tumors. Most cited examples are oncofoetal antigens the first proteins that were used as circulating tumor markers.

The expression of such molecules may explain why the embryonic environment influences the cancer cell phenotype. In coculture with human embryonic stem cells, used as a surrogate embryonic environment, the aberrant expression and secretion of the TGF- $\beta$ - related morphogen nodal was downregulated in metastatic melanoma and breast carcinoma cell lines, making them more sensitive to apoptosis, less clonogenic and less tumorigenic (Postovit et al., 2008). Lefty, an inhibitor of nodal signalling, exclusively secreted by human embryonic stem cells and not expressed in cancer cells

Abbreviations used in this paper: $\mathrm{BM}$, bone marrow; BMDCs, bone marrow-derived cells; CAFs, cancer-associated fibroblasts; COX, cyclo-oxygenase; CSC, cancer stem cell; E2, oestradiol; ECM, extracellular matrix; EGF, epidermal growth factor; EMT, Epithelial to Mesenchymal Transition; EPC, endothelial precursor cell; ER, oestrogen receptor; FAK, focal adhesion kinase: FGF, fibroblast growth factor; GPCR, G-protein-coupled receptor; HER2/neu, Human epidermal growth factor receptor; same as ErbB-2; HSP, heath shock protein; HPC, hematopoietic precursor cell; IFN, interferon; IL, interleukin; LOX, lysyl oxidase; MAPK, mitogen-activated protein kinase; MDSC, myeloid-derived suppressor cell; MET, Mesenchymal to Epithelial Transition; MMP, matrix metalloproteinase; MMTV, mouse mammary tumor virus; PDGF, platelet-derived growth factor; PIGF, Placental growth factor; $\mathrm{PR}$, progesterone receptor; RANK, receptor activator of nuclear factor kappa$\mathrm{B}$; ROS, reactive oxygen species; SMA, smooth muscle actin; SF/HGF, scatter factor/hepatocyte growth factor; TAMs, tumor-associated macrophages; TGF, Transforming growth factor; uPA, urokinase-type plasminogen activator; VEGF, vascular endothelial growth factor.

\footnotetext{
*Address correspondence to: Marc M. Mareel. Department of Radiotherapy and Experimental Cancer Research, University Hospital Ghent, De Pintelaan, 185, B-9000 Ghent, Belgium.Tel: +32-332-3078. e-mail: marc.mareel@ugent.be
} 
was directly associated with the reprogramming of the cancer cells towards a less malignant phenotype. These experiments show that cancer cells not only express embryonic signaling pathways but are also sensitive to the embryonic modulators of these pathways. Alternatively, the embryonic environment may "prime" cancer stem cells, as exemplified by the intrauterine hormonal and nutritional milieu being an independent correlate of breast cancer risk in adulthood. Such "fetal origins of breast cancer" are explained by epigenetic modifications leading to changes in mammary gland development, that render the epithelial stem cells more sensitive to malignant transformation (Hilakivi-Clarke et al., 2006).

Invasion, the local occupation by cancer cells of tissues other than their tissue of origin, and metastasis, the occupation by cancer cells of distant organs, are the hallmarks of malignancy and a major cause of therapy failure. These phenotypes depend upon the interaction between the cancer cells and the host tisue, called respectively the "seed" and the "soil" by Stephen Paget in 1898. The "seed" and "soil" theory has been firmly substantiated and its molecular basis is by now well documented, the "seed" being renamed to the cancer initiating cell or cancer stem cell and the "soil" to host factors, stroma or microenvironment (Fidler and Poste, 2008). Together this interaction establishes ecosystems that constitute the basis of the disease called cancer (Mareel et al. , 2009). It mimicks the ecosystems that support the development of the normal organism with one striking difference: Metastasis, implicating transport through the vasculature of non-hematopoietic cells, is a rare event in embryonic development.

In the present review, we will apply the ecosystem concept of invasion and metastasis to mammary cancer and mammary gland development. The following ecosystems will be considered: Cellular ecosystems comprising molecular pathways that steer the cellular activities involved in programs of invasion and metastasis; Subpopulations of epithelial cells interacting with each other; Epithelial and stromal compartments interacting with each other within distinct cancerous or normal ecosystems; Distant ecosystems, interacting through the circulation and comprising primary tumors, endocrine organs, bone marrow and distant metastases.

Citation of the literature will not be exhaustive and priority will be given to references that were not included in our previous review (Mareel et al., 2009).

\section{Cellular ecosystems: programs of invasion}

Invasion and metastasis, considered as a multistep invasion process, operates on the basis of programs, implicating various cellular activities, namely proliferation, cell-cell adhesion, cell-matrix adhesion, proteolysis, migration and survival via escape from apoptosis, from anoikis or from other forms of cell death. These activities mobilize molecular pathways within cellular ecosystem (Fig. 1). In older reviews we have associated each of these activities with an index molecular complex, which is, however, also implicated in one or more of the other cellular activities. Moreover, these molecular complexes do branch and interact with other pathways so establishing an extremely complicated and very flexible intracellular ecosystem, that might be approached through the discipline of systems biology. In such ecosystems, modulation of one element may change the whole system. Pathways implicating molecules of the same families building similar networks are operative in mammary cancer invasion and in gland morphogenesis. In the latter, more emphasis was put on phenotypes, like terminal end bud formation, branching and involution, than on separate cellular activities. Important and not discussed in detail in the present review is the influence of hormones on these pathways.

Growth factors and their receptors, many of which belong to the tyrosine kinase family, not only modulate cell proliferation but also signal to migration, cell-cell adhesion and survival, as is suggested by double names like SF/HGF and as illustrated by the EGFR pathway (Sabe et al., 2009). Growth factor receptors, their agonists and their antagonists involved in branching morphogenesis are listed by Fata et al. (2003) and by Sternlicht (2005). Kinetics may determine the cellular response to growth factors signallling through the same pathway. In primary mammary organoids isolated from virgin mice, the duration of activation influences the response of the ecosystem. Sustained (1 hour) activation of MAPK by TGF- $\alpha$ leads to branching, whereas transient (15 minutes) activation of MAPK by FGF-7 causes growth but no branching (Fata et al., 2007).

Survival at ectopic sites, local tissues or distant organs, through escape from anoikis, a particular form of apoptosis, is a prerequisite for cancer invasion and metastasis. Accordingly, higher expression of the death receptorgene Fas is associated with a better prognosis (Kumar et al., 2000). During mammary gland involution apoptosis serves a physiological role; genes involved in this process are listed in Kumar et al. (2000). A family of inhibitors-of-apoptosis-proteins are downregulated prior to gland involution. Such proteins have BIR domains that target them to inhibit caspases and they are counteracted by the activator of caspase SMAC and by the stressregulated endoprotease OMI ( Owens et al., 2010).

The E-cadherin/catenin complex interacting with its homologue on a neigbouring epithelial cell is primarily associated with epithelial cell-cell adhesion and, therefore, an essential element of the development of epithelial structures like the mammary gland. One of its elements, namely $\beta$-catenin, plays a pivotal role in the Wnt-signaling pathway driving cell proliferation (Hatsell et al., 2003). In cancer, the E-cadherin/catenin complex is considered as an invasion-suppressor. In lobular breast carcinoma, E-cadherin is downregulated by inactivating mutations; in ductal carcinoma the downregulation is transient and sometimes associated with upregulation of other cadherins like $\mathrm{P}$-cadherin and $\mathrm{N}$-cadherin, both being considered as invasion promoters and markers of worse prognosis (Berx and Van Roy, 2001). Normally, E-cadherin is expressed by mammary epithelial cells, whereas P-cadherin is found in myoepithelial cells and in cap cells of the ductal terminal end buds.

Integrin is the common name of 24 heterodimeric combinations of an $\alpha$ and an $\beta$ subunit. They span the plasma membrane, regulating cell-matrix adhesion by forming inside complexes with multiple intracellular components, most prominently FAK, and outside complexes with the elements of the ECM. Through their impressive panel of intracellular signalling pathways they influence also the other cellular activities that are implicated in cancer invasion and mammary gland development (Katz et al., 2007; Kass et al., 2007; Pontier and Muller, 2009; Guan, 2010). For example, the tyrosine kinase cell surface receptor ErbB2-mediated anchorage independence and escape from anoikis requires integrin $\alpha 5$ (Haenssen et al., 2010). Also implicated in mammary gland branching and cancer invasion are nonintegrin ECM receptors, such as galectin and the DDR1 tyrosine kinase (Fata et al., 2003).

Proteases, mainly MMPs and their inhibitors, operating as 
secreted molecules or anchored at the plasma membrane, serve matrix degradation creating roads for invading cells in cancer and for epithelial branching during mammary gland development (Radisky and Radisky, 2010). Next to paving the way for migration, MMPs affect branching morphogenesis through proteolysis of the ECM, causing loss of ECM/integrin signalling and generating bioactive ECM fragments as well as growth and motility factors that are sequestered by the ECM. Moreover, MMPs loose cellcell adhesion molecules and shed soluble fragments that initiate autocrine morphogenic signalling (Fata et al., 2003; Sternlicht, 2005). All these molecules serve as signals for most if not all cellular activities and their index molecular complexes. Some MMPs are asssociated with specific stages of evolution, e.g. MMP2 with ductal elongation and MMP3 with lateral branching. That epithelial cells can migrate through the covalently cross-linked natural ECM in a protease-independent amoeboid way has been questioned (Saheb et al.,,2008).

Motility factors are found amongst the abovementioned growth factors; they signal through receptor tyrosine kinases, such as EGFR and the scatter factor receptor c-MET. Chemokine receptors are GPCRs, responding to one or more chemokines and linked to a cascade of downstream signals, explaining why chemotactic cytokines modulate directed migration, as well as proliferation and apoptosis (Ali and Lazennec, 2007). Highly expressed in breast cancer are the receptors CXCR4, binding CXCL12, and CCR7, binding both CCL19 and CCL21 ligands. CCL 21 is abundant in lymph nodes explaining the prevalence of breast cancer metastasis to this lymphoid organ. Chemotactic migration onto various chemokines of cancer cells expressing these receptors is demonstrated in transwell assays. Stimulation of proliferation is more restricted to the receptors for CXCL12, namely CXCR4 and CXCR7. Cancer cells produce also chemokines, implicated in recruitement of leukocytes and endothelial cells expressing the cognate receptors. Endothelial cells may also express the decoy receptor, DARC, interacting with the metastasis suppressor KAl1 to induce senescence of the extravasating cancer cell (liizumi et al., 2007).

The cursory overview of signalling from the index molecular complexes illustrated in Fig. 1 demonstrates the complexity of the intracellular ecosystem and its great versatility in expressing invasion-related programs in cancer and in mammary development. Much discussed examples of such programs are EMT and MET describing transitions between the epithelial and the mesenchymal phenotypes and illustrating similarities between cancer invasion and metastasis as compared to developmental invasion (Kalluri and Weinberg, 2009; Micalizzi et al., 2010). The completion of EMT is characterized by degradation of the epithelial basement membrane and formation of a mesenchymal cell that can migrate away from its epithelium of origin. Next to invasion, EMT/MET has other functional consequences that contribute to the maintenance of the tumor, namely escape from host immune attack and resistance to therapy.

EMT has been categorized into three subtypes based on the biological context in which they occur and each subtype is characterized by a panel of molecular markers. Type I occurs in embryonic development. Type II is associated with inflammation and occurs in fibrosis and wound healing. Type III occurs in cancer; here, MET is described in metastases, after vascular transport of cells that underwent EMT (Zeisberg and Nelson, 2009).

At secondary branching, terminal end buds bifurcate under regulation by EGF, SF/HGF and MMPs, proteins that are also implicated in cancer-associated EMT.

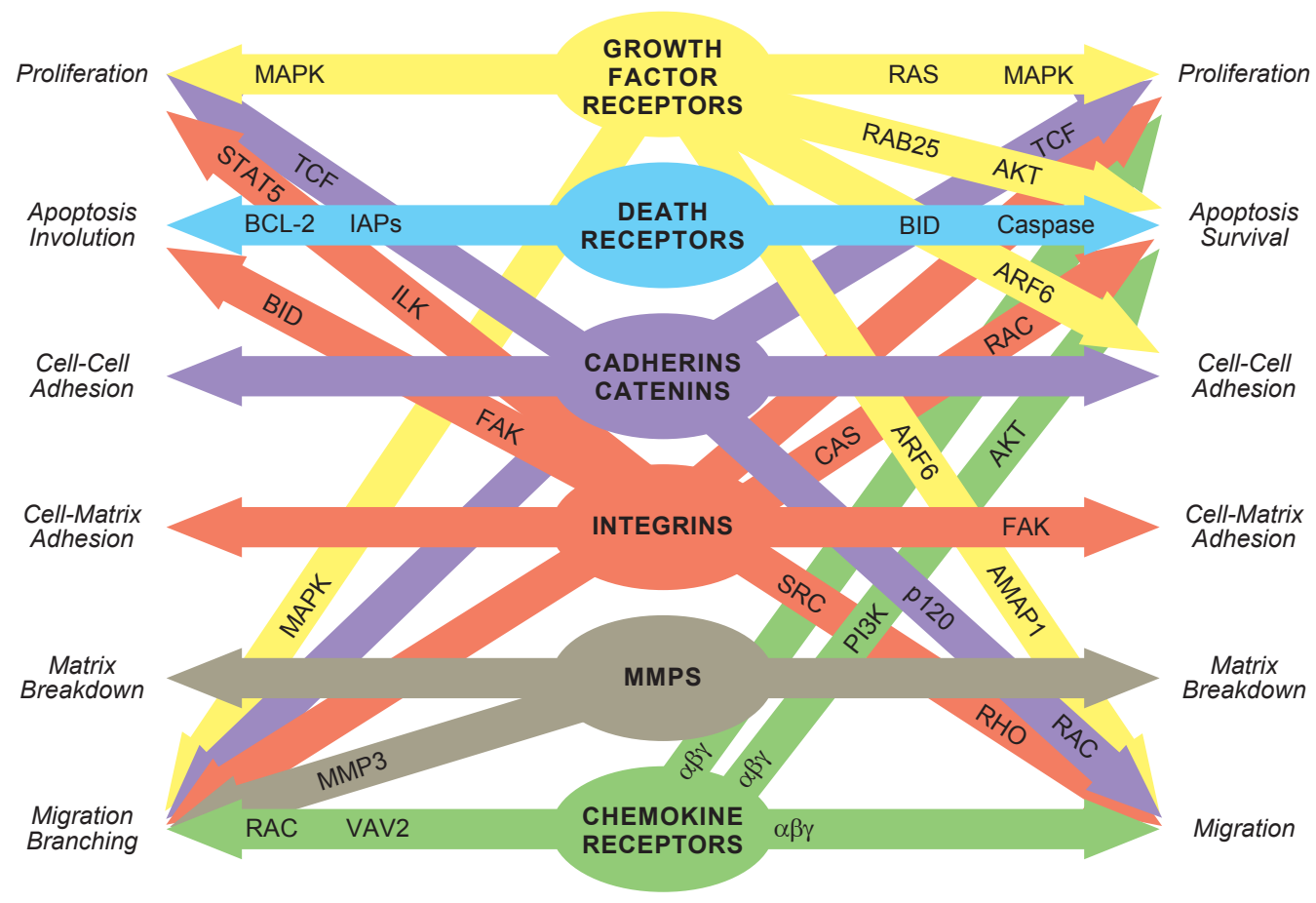

Fig. 1. Cellular activities and their index molecular complexes participating in invasion programs in breast cancer (right side ) and in mammary development (left side). To illustrate the complexity and interaction of the pathways, some key signalling molecules, belonging to various families, are indicated. Manipulation of each of these elements may alter the whole ecosystem and change the invasion program. $\alpha \beta \gamma$, trimeric G-proteins; $A K T(=P K B)$, protein kinase $B ; A R F 6$ $R A S, R A B, R A C, R H O$ are members of the family of small GTPases; AMAP1 is an ARF-GAP ( GTPaseactivating protein); $B C L-2$ is a family of apoptosis regulators, some pro-and others antiapoptotic; BID is a proapoptotic member of the BCL-2 family; CAS, Crk-associated substrate; FAK, focal adhesion kinase; IAPs, Inhibitors-of-Apoptosis-Proteins; ILK, integrin-linked kinase; MAPK, mitogen-activated protein kinase; MMP, matrix metalloproteinase,

p120, p120 catenin; PI3K, phosphatidylinositol 3,4,5,-triphosphate; SRC is a protooncogene tyrosine kinase; STAT5, Signal transducer and activator of transcription 5; TCF, a nuclear transcription factor that stabilizes $\beta$-catenin; VAV2, a guanine nucleotide exchange factor (GEF). Adapted from Mareel et al. (2009) with data from: Sabe (2009); Fata et al., (2007); Pontier et al. (2009); Duan et al. (2010); Owens et al., (2010); Subramani and Alahari, (2010). 
EMT regulators like the transcription factors SNAIL/SLUG and TWIST, the homeobox protein SIX1 along with interconnecting signaling pathways including Wnt, TGF- $\beta$ and other growth factors, RAS and other GTPases, are implicated in mammary development and are frequently misexpressed in breast cancer (Guarino et al., 2007; Micalizzi et al., 2010). Affymetrix gene profiling revealed 28 named genes that are involved in EMT, TGF- $\beta$ and Wnt signaling and that were differently expressed in invasive ductal carcinoma as compared to lobular carcinoma (Turashvilli et al., 2007). In a cohort of triple-negative, ER-, PR- and HER2/neu-negative, breast cancers, Henessy et al. ( 2009) found a naturally occuring relatively chemoresistent subset that were enriched in EMT and stem cell characteristics. The importance of EMT/MET in cancer progression has been a matter of debate, as discussed previously (Mareel et al., 2009). In particular, the lack of molecular markers for EMT-derived cells leaves us with the possibilty that they are of stromal and not of epithelial origin. Direct evidence for EMT in breast cancer came from experiments with transgenic MMTV tumor-bearing mice, in which tumor epithelial and stromal cells were genetically marked in an independent manner so that their fate could be determined during tumor progression (Trimboli et al., 2008). In this model, EMT was a rare event and it appeared to be driven by the oncogene $m y c$, in line with the observation that in human breast cancer EMT is associated with myc amplification. The authors concluded that neither in their transgenic mice nor in human, EMT is a prerequisite for invasivenes and metastasis but rather facilitates it. What constitutes the essential difference between the well-defined developmental EMT, and the less predictable cancer EMT is an open question.

\section{Interaction between various subpopulations of the epithelial compartment}

Epithelial cell compartments, in the normal mammary gland and in cancers, are heterogeneous (Fig. 2). They are derived from stem cells evolving into various subpopulations that dynamically interact with one another. Such interaction has been coined cooperativity, community effect, or heterotypic signaling. Stem cells constitute an essential subpopulation as they have self-renewal capacity and the ability to differentiate into multiple cell types. The non-epithelial compartment is described as the stroma (cfr infra). The fact that the epithelial cells may take phenotypes resembling stromal cells, a phenomenon termed mimicry, transdifferentiation or transition, has lead to confusion about strict separation of the two compartements (Monks et al., 2008).

\section{Epithelial stem cell interaction}

The first proposal for human breast epithelial stem cells came from the analysis of tissue cultured normal breast epithelium (Hammond et al., 1984). The difficulties in using such cell lines for human breast cancer-specific malignant transformation are discussed by Petersen and Polyak (2010). They concluded that "whereas human breast epithelial stem cells may exist within the basal layer, the luminal compartment or its reprogrammed equivalent can also provide precursor cells for breast cancer". Such aberrant luminal progenitors with the stem cell growth factor tyrosine kinase receptor C-KIT as a key marker, provide a candidate target population for basal tumor development in carriers of BRCA1 mutations (Lim et al., 2009). CSCs are sensitive also to changes in the tumor ecosystem. For example, repetitive cycles of hypoxia and reoxygenation may lead to the enrichement of breast CSC (CD44-positive/CD24negative/ESA-positive) in populations of MDA-MB231 and BCM2 cells (Luoie et al., 2010). This subpopulation may be the seeds of metastasis in line with the observation that CD44-positive/CD24low or -negative cells in parafin sections from untreated primary tumors mark a higher frequency of distant metastasis, particularly in the bone (Abraham et al., 2005).

At the stage of branching morphogenesis, the epithelial com-

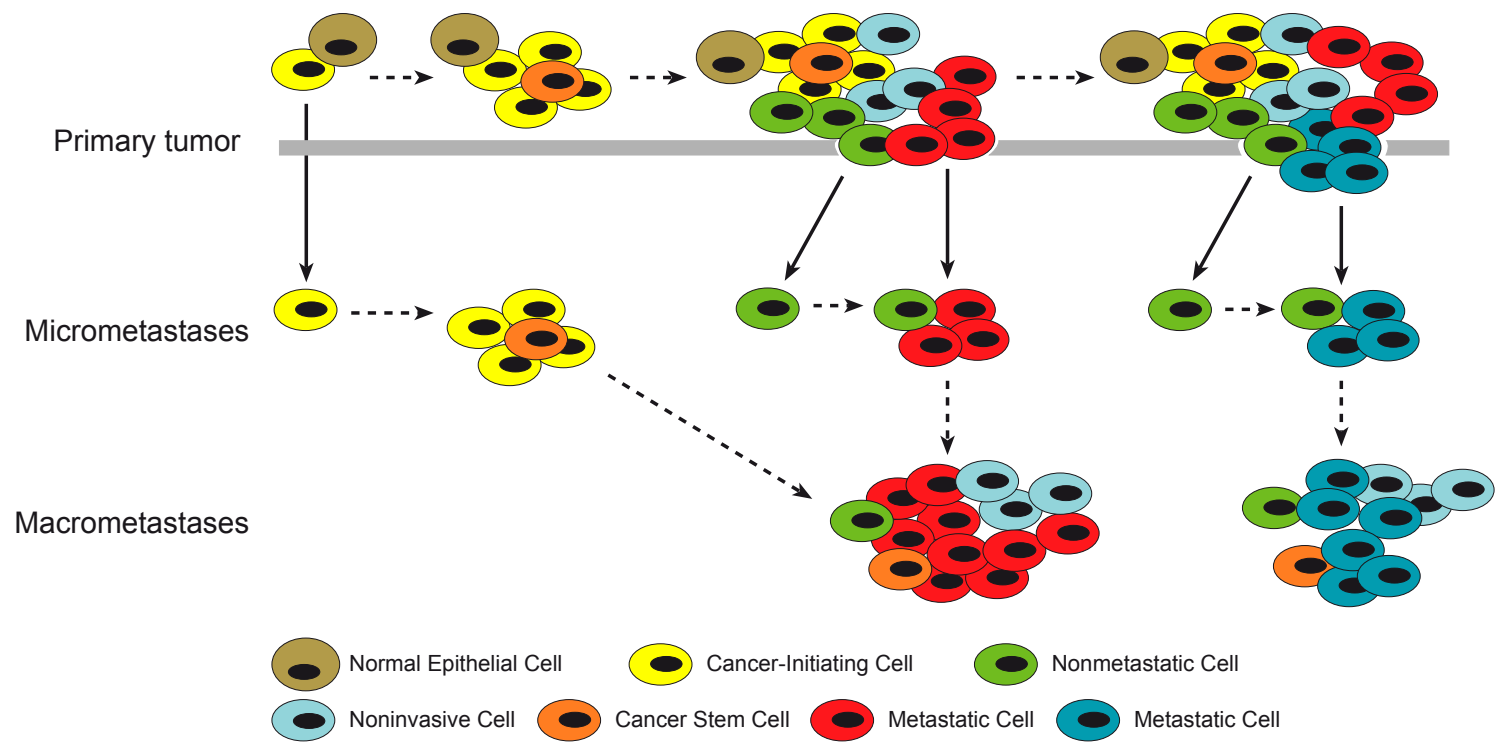

Fig. 2. Heterogeneity of the epithelial cell population during development of metastatic cancer. Dashed arrows, progression in time; solid arrows, displacement of cells; thick gray line, epithelial basement membrane. Stromal cells are not represented in the schematic. Adapted from Mareel et al. (2009) with data from: Tsuji et al. (2009); Pontier and Muller (2009); Navin et al. (2011). 
partment of the mammary gland terminal end bud consists of luminal epithelial cells, myoepithelial cells, body cells and cap cells (Sternlicht, 2005). They interact with one another, as exemplified by the laminin-like protein NETRIN-1 produced by the body cells, binding to its receptor neogenin on cap cells and so stabilizing the cap. Interaction between these epithelial cells participates at the collective cell migration that drives branching morphogenesis (Friedl and Gilmour, 2009; Rorth, 2009) as evidenced by dynamic morphological observations on freshly isolated mammary epithelium in 3-dimensional Matrigel gels (Ewald et al., 2008). Terminal end buds are different from quiescent ducts : they have muliple luminal cell layers, are enriched in mammary stem cells and show high levels of proliferation. They reorganize into a multilayered epithelium, migrate collectively and rearrange dynamically but they remain adherent to one another keeping their E-cadherin/catenin complexes at cell-cell contacts. Myoepithelial cells are put forward as regulators of this dynamic tissue architecture. How the moving buds find their direction remains, however, unclear.

\section{Interactions between cancer cell populations}

Cancer cell populations are heterogeneous, also with regard to their invasive and metastatic competence, and this heterogeneity is created partly through interaction with the host, (Nicolson et al., 1978). Subpopulations may interact to stimulate or to retard tumor development and progression at both the primary and the metastatic site. Such interaction was termed community effect by Jouanneau et al. (1994) using the rat NBT-Il bladder cell model where interaction through acid FGF resulted in tumor progression with shortening in the delay of metastasis. Acommunity effect, also called class action, applies to cancer cells which fail to metastazise by themselves but facilitate the metastasis by other cells at three steps (Bidard et al., 2008 and refs cited there): One. During invasion through the ECM, collective migration represents an efficient dissemination strategy, with primary migrating cells changing the ECM, creating tunnels and conditioning the substrate. The mode of migration may even determine the route of metastasis, lymphatic spread being restricted to collective migration and hematogeneous spread associated with single cell migration. Emboli of heterogeneous subpopulations are another example of the efficiency of collective migration in metastasis. Two. Premetastatic niche conditioning may occur through the release of nonmetastatic cells into the circulation. Such cells are found, indeed, in the circulation of nonmetastatic primary tumors. They may condition the metastatic ecosystem by activation of the endothelium and cluster formation, permitting homing of waves of circulating cancer cells. Bidard et al., (2008) suggest that the chemokine-secreting subclones of the primary tumor are responsible not only for the recruitment of metastasis-facilitating bone-marrow cells (cfr infra) but also serve as a niche for other tumor subclones. The observation that the combination of cancer cells in the bone marrow detected 3 years after treatment together with circulating cancer cells heralds a worse prognosis (Wiedswang et al., 2004) is in line with Bidard's (2008) opinion that the bone marrow cancer cells condition the niche where the circulating cancer cells will ultimately form a metastasis. Three. Final growth and formation of macrometastases may result from the colonization of micrometastases, explaining the heterogeneity of metastasis and the similarities in genetic profiles between primary tumors and distant metastases (Mareel et al., 2009). Cooperativity at the ecosystem of metastatic colonization, providing an alternative interpretation of EMT/MET in metastatic cancer has been put forward by Tsuji et al. (2009). Cells that underwent EMT are responsible for invasion at the primary site and extravasation at the site of metastasis, where they are, however, unable to proliferate. They pave the way for non-EMT cells that do colonize the niche and form macrometastases, so that MET is not needed to explain the epithelioid, E-cadherin-positive character of the metastases. Cooperativity between subpopulations of cancer cells and sequential homing in waves may be one possible way to explain metastatic dormancy (Suzuki et al., 2006).

\section{Interaction between benign and malignant epithelial cells}

Mixed cultures of cells, used as surrogates for more benign and more malignant epithelial subpopulations, suggest both stimulation and inhibition of cancer cells by adjacent more benign epithelial cells. Examples of stimulation include: MCF-10A cells enhancing the transformed phenotype of MDA-MB231 cells, evidenced by colony formation and tumorigenicity and explained as contact-mediated stimulation of MDA-MB231 by autocrine growth factors (Poczobutt et al., 2010); Induction of MCF-7 cell motility by human mammary epithelial cells HMEC or their conditioned medium through as yet unknown factors (Carpenter and Nguyen, 1998); Stimulation of invasion of three breast cancer cell lines through long-term co-incubation with conditioned medium from normal breast epithelial cells HB2 through an HB2 cell-released chemokine CXCL12 binding to the cancer cell-expressed CXCR4 receptor leading to overexpression of UPAR (Serrati et al., 2008). Examples of inhibition include: Normal mammary epithelial cells NME retarding growth of MCF-7 cells (Quarrie et al., 1999); Normal breast epithelial cells NBEC inducing p53-dependent apoptosis and p53-independent cell cycle arrest of breast cancer cells (Toilon et al., 2002); Conditioned medium from noninvasive breast cancer cells MCF7 that overexpress microRNA 17/20 interfering with MDA-MB-231 cell migration and invasion through inhibition of heterotypic secreted pro-migratory signals (Yu et al., 2010). In experiments with the MCF-7 cell family, a minority of noninvasive MCF-7/AZ cells corrected loss of cell-cell adhesion in a majority of invasive MCF-7/6 cells (Fig. 3). Also considered as suppressors of cancer cell invasion are myoepithelial cells as reviewed earlier (Mareel et al., 2009)

\section{Interaction between stromal and epithelial compartments}

The stromal compartment consists of resident and recruited cells, most of mesenchymal origin, and their products coined ECM. The stroma is separated from the epithelium by an intact basement membrane, partly produced by the epithelium. In cancer the basement membrane is degraded, bringing both compartments into direct contact and initiating neovascularisation, influx of inflammatory cells and extensive remodeling of the ECM. The ECM forms an informational entity per se in the sense that it receives, imparts, and integrates structural and functional signals (Hodges and Rowlatt, 1994). Mutual interactions between stroma and epithelium modulate embryonic organogenesis, adult maintenance of organ homeostasis and cancer development. Such interactions not only promote but also suppress cancer progression sometimes through subtypes of the same type of cells (Bissell and Hines, 2011).

Embryonic mammary epithelium when recombined with salivary gland mesenchyme undergoes a kind of branching that resembles 


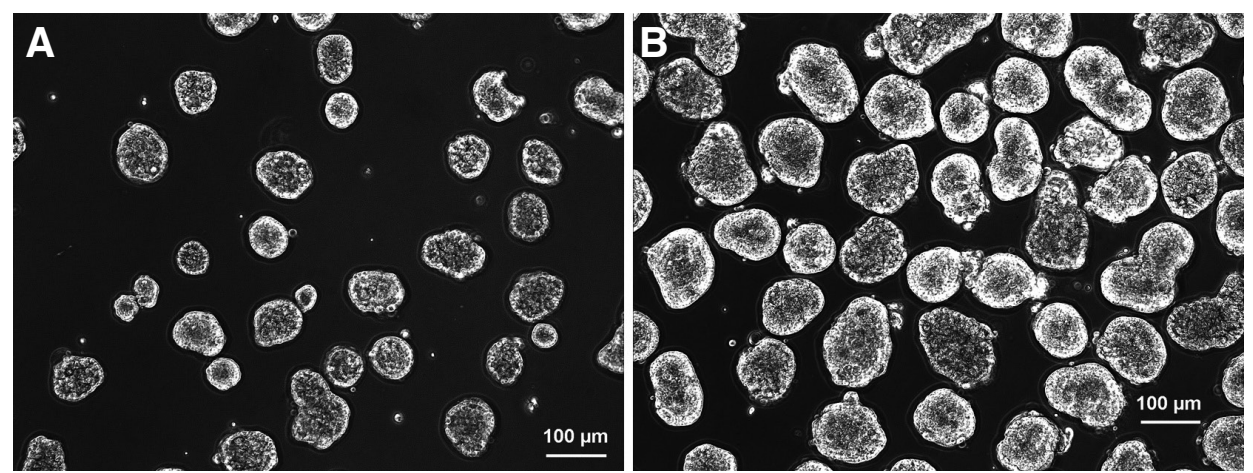

Fig. 3. Macroscopic pictures of cellular spheroids formed by invasive MCF-7/6 cells alone (A) or admixed with $10 \%$ non-invasive MCF-7/AZ cells (B) and cultured on a Gyrotory shaker for 3 days. (Experiment performed by M. Bracke, UGent, Ghent, Belgium)

morphogenetically salivary gland, though the epithelium remained sensitive to endogenous hormonal stimuli with production of milk proteins (Sakakura et al., 1976). Hormonal modulation of organogenesis acts through epithelium-induced expression of hormone receptors on the mesenchym, which on its turn is directed by the hormones to influence the epithelium (Heuberger et al., 1982). Recombinations of tissues from androgen-insensitive and wild type mice in vitro showed that testosterone induces detachment and degeneration of mammary buds via the mesenchym (Drews and Drews, 1977). Key endocrine pituitary and ovarian signals that regulate mammary branching morphogenesis via stromal cells are summarized by Sternlicht (2005).

It was the work of Paul Basset that revealed the participation of stromal factors at cancer invasion (Basset et al., 1990; Masson et al., 1998) showing the crucial role of the secretion by stromal cells of matrix metalloproteinase MMP-11 (stromelysin 3) in mammary cancer (Fig. 4). Intercompartmental interactions are not limited to the primary tumor but also take place in metastasis. For example, stromal cells and ECM implicated in breast cancer liver metastasis comprise: hepatic stellate cells; Küpffer cells; several types of collagen and laminin (Tabariés and Siegel, 2011), Also involved at this secondary site are the normal parenchymal cells, in casu hepatocytes. The elements of the stromal compartment do interact not only with epithelial cells but also with one another, as detailled for the interaction of myofibroblasts with various other stromal cell types in our previous review (Mareel et al, 2009). Their behaviour is modulated by the ecosystem as evidenced by spinning disk confocal microscopy visualizing stromal cells in living mice and
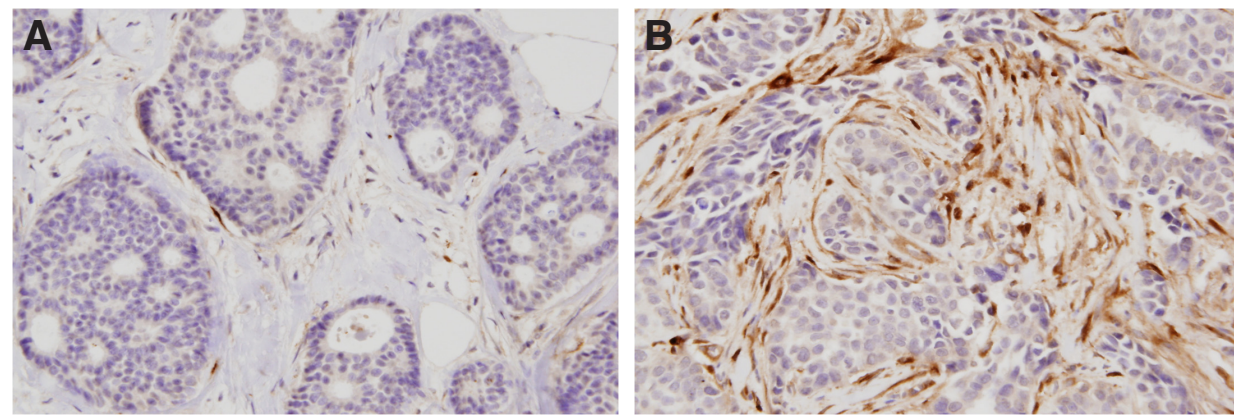

Fig. 4. Immunocytochemistry of matrix metalloproteinase (MMP)-11, also called stromelysin-3 (ST3), in non-invasive (A) and invasive (B) breast cancer. (Observation by M.-C. Rio, IGBMC, Strasbourg, France, illustrating Paul Basset's original observation, mentioned in the text.). showing that the migration of leukocytes, macrophages and fibroblasts differs pending upon the environment within the same mouse (Egeblad et al., 2008).

Pathological examination of tumors reveals the participation of the stroma as: Angiogenesis with newly formed blood vessels and lymph vessels; Inflammation and immune response represented by leukocytes and macrophages; Desmoplasia consisting of carcinoma-associated fibroblast (CAFs) and ECM. Participating at the establishment of the ecosystems also are: adipocytes, nerves and, in bone metastasis, osteoblasts and osteoclasts.

\section{Endothelial cells and angiogenesis}

The participation of blood-and lymphangiogenesis at tumor progression has been extensively covered by the recent literature. The overall scenario describes a paracrine modulation through the balance between suppressors, such as angiostatin, and promoters, belonging to the VEGF family, produced by the cancer cells, binding to their cognate receptors on the endothelial cells and so stimulating proliferation, migration and ectopic survival (Cebe-Suarez et al., 2006). VEGF is highly expressed in breast cancer and it represents a major target for therapy (Ellis and Hicklin , 2008).

In view of the ecosystem concept, it is of interest to consider the hormone-sensitivity of angiogenesis. Estrogens and progestins may stimulate the expression of VEGFs in breast cancer cells (Hyder et al., 2009a; Mafuvadze et al., 2010). One possible mechanisms is through binding of the E2/ER $\alpha$ complex to the promoter of HIF-1 $\alpha$ a well know stimulator of VEGF transcription (Ogba et al., 2010). In genetically manipulated MCF-7 cells, the ER $\alpha$ complexes interact with c-MYC to bind to the VEGF promoter (Dadiani et al., 2009). Nuclear accumulation of angiogenin, a member of the RNase superfamily, is essential for angiogenic activity and its increased expression may transform normal breast tissue into invasive carcinoma. Angiogenin is stimulated by $\mathrm{E} 2$ and counteracted by the ER antagonist tamoxifen (Nilsson et al., 2010). Using breast cancer cell lines, Harfouche et al. (2011) showed a negative correlation between the expression of angiopoietin -1 , a ligand for the endothelial tyrosine kinase receptor Tie-2, and levels of ERo and a positive correlation with angiogenesis. Angiopoietin -1 was downregulated by E2 in an ER $\alpha$-dependent manner and differences between $\mathrm{ER} \alpha$-positive and $\mathrm{ER} \alpha$-negative tumors disappeared after ovariectomy. Other angiogenic molecules are also sensitive to estrogens and progestins, as exemplified by trombospondin-1 (Hyder et al., 2009b).

The normal mammary gland, as analyzed by the mercox methyl methacrylate corrosion cast technique, displays angiogenic expansion during pregnancy and lactation through sprouting and intussusception respectively; during involution, ordered regression takes place through collapse of the honeycomb structures, capillary retraction, endothelial attenuation 
and apoptosis (Djonov et al., 2001). VEGFs and VEGFRs are increased during pregnancy and lactation in both the epithelium and the stroma; such response of VEGF/NEGFR to physiological needs is in striking contrast with the sustained elevation in breast cancer (Pepper et al., 2000; Islam et al., 2010). Inactivation of VEGF in the epithelium of transgenic mice compromises mammary gland development and function (Rossiter et al., 2007). The endogenous antiangiogenic splice isoform of VEGF, VEGF165b, is normally expressed in nonlactating human and mouse breast and is down-regulated in wild type mice during lactation. Transgenic mice show that this downregulation is a prerequisite for effective milk production (Qiu et al., 2008),

\section{Leukocytes, macrophages, inflammation and immunity}

Today, the role of immunity and inflammation in cancer progression is a major issue (Egeblad, 2008; Grivennikov et al., 2010) and macrophages are considered by some authors as obligate partners for cancer cell migration, invasion and metastasis; they are put forward as crucial therapeutic targets (Condeelis and Pollard, 2006; Hagemann et al., 2005; Sica et al., 2006).

Recent clinical observations support the protumoral role of M2 subtype macrophages called TAMs (Laoui et al., 2011). In two independent cohorts of breast cancer, proliferating TAMs marked as CD68- and PCNA-positive were associated with poor prognosis (Campbell et al., 2010). The decreased incidence but increased cancer aggressiveness associated with parity is explained by an increase in the macrophage population as demonstrated in primiparous as compared to virgin rats (Zhao et al., 2010). During postlactational regression, mammary cells develop a program with secretion of cytokines, IFN- $\gamma$, IL-12a, IL-4 and IL-13, signaling through STAT3 and NF-kB and associated with an acute inflammatory response (Watson, 2009). The postpartum involuting mammary gland shows an eightfold increase in M2 macrophages, with a phenotype determined by high arginase and low inducible nitric oxide synthase in mouse and by mannose receptor expression in humans. Peaking also are M2 cytokines, IL-4 and IL-13 (O'Brien et al., 2010).

Mechanisms of interaction between breast cancer cells and macrophages comprise: Mutual triggering of the expression of IL-1 $\beta$ in both cells, leading to increased COX-2 in cancer cells via the ROS/ SRC/ MAPK/AP-1 pathway as evidenced by cocultures of THP-1 cells with HCC1937 cancer cells (Hou et al., 2011); Secretion of very high amounts of HSP27 by cancer cells causing differentiation of monocytes to macrophages that lose tumoricidal activity and become pro-angiogenic (Banerjee et al., 2011); Transcription factor FRA-1-dependent stimulation of invasion, angiogenesis and metastasis in 4T1 cell populations by RAW macrophage production of MMP-9, VEGF, TGF- $\beta$ (Luo et al., 2010); Feed-forward loops with activation of NF-KB in leukocytes inducing production of cytokines that activate NF-кB in cancer cells followed by production of cytokines that attract more leukocytes into the tumor (Grivennikov et al., 2010). Macrophages may also mediate effects of other stromal cells or act through them. Loss of TGF- $\beta$ signalling in mammary fibroblasts leads to an increase in secretion of the cytokine CCL2 causing progression of 4T1 tumors either through direct action on the cancer cells or through recruitment of macrophages (Hembruff et al., 2010). In three mouse models, the prometastatic program in macrophages is driven by the transcription factor ETS2, suppressing anti-angiogenic genes. Accordingly, in human cancers an Ets2-TAM expression signature retrospectively correlated with overall survival (Zabuawala et al., 2010).

Tumour-infiltrated regulatory T cells stimulate mammary cancer metastasis through RANKL-RANK signalling to IKK- $\alpha$ causing suppression of the antimetastatic serinproteinase inhibitor maspin and favouring survival of circulating metastasis-inducing cancer cells (Tan et al., 2011a). Immunostaining of sections from experimental and human tumors showed a pattern of CD4/CD25/FOXP3-postive regulatory Tcells that were identical to the pattern of RANKL-positive cells; both kind of positive cells were in contact with $\alpha$-SMA-positive CAFs. A probable scenario is that CAFs express CCL5 attracting CCR1-expressing regulatory T cells that produce RANKL and so promote metastasis in RANK-positive tumors. Regulatory $T$ cells also secrete IL-4 and IL- 13 activating M2 macrophages and so stimulating metastasis (DeNardo et al., 2009). These observations explain why immunosuppressive $T$ cells are associated with aggressive breast cancer phenotypes, such as triple-negatives and higher Nottingham scores (Bohling and Allison, 2008) and lead to a worse outcome when present and activated in lymphoid infiltrates surrounding breast cancer (Gobert et al., 2009).

\section{Myofibroblasts and desmoplasia}

The pro-invasive and pro-metastatic activity of myofibroblasts in breast and other tumors have been recently reviewed (De Wever et al., 2008; Abboussekhra, 2011). The scenario describes the conversion, by the non-invasive cancer cells, of fibroblasts into pro-invasive myofibroblasts. This scenario is refined by the participation of interstitial flow stimulating MMP activity and, so, making TGF- $\beta$ more available, degrading collagen and enhancing fibroblast migration (Shieh etal., 2011). Phenotypically, CAFs closely resemble myofibroblasts, first defined ultrastructurally by Gabbiani and colleagues in experimental wound-healing (Gabbiani et al., 1971). They are characterized by abundant rough endoplasmic reticulum, smooth muscle actin filaments and a fibronexus comprising the extracellular component of the cell-to-matrix junction. Markers for the identification of myofibroblast include: vimentin, $\alpha$-SMA, non-muscle myosin and EDA-fibronectin.

Gene expression profiles of laser-capture microdissected tumorassocated host cells from primary breast tumors yielded prognostic signatures associated with a poor disease-specific survival (Finak et al., 2008). Serum-activated fibroblast cultures showed a signature with genes implicated in tissue remodeling, migration, angiogenesis and inflammation. This "wound-response" signature heralded reduced overall survival and distant metastasis-free survival in breast cancer (Chang et al., 2005). A large number of the proteins encoded by genes in the abovementioned signatures are expressed by myofibroblasts, as evidenced by immunohistochemical analysis of breast tumors. Interestingly, CAFs are stimulated by estrogens via a nuclear alternate estrogen receptor GPR30 that interacts directly with EGFR and so signals to immediate early gene expression (Madeo and Maggiolini, 2010).

The prognostic significance of CAFs is illustrated also by their increased expression of PDGF- $\beta$ R, lysyl oxidase-like-2, caveolin-1 and CD10 in cancers with worse outcome (Paulsson et al., 2009; Sloan et al., 2009). Probability of distant metastasis was predicted independently by immunohistochemical analysis of myofibroblastassociated $\alpha$-SMA (Yamashita etal., 2010). Paracrine and autocrine communication between CAFs and cancer cells and CAFs and other stromal cells implicates multiple ligands, recognizing their 
cognate receptor on the partner cell; it contributes to the transition from the "normal" to the pro-tumoral state of the stromal cells (Mareel et al., 2009). In the primary tumor ecosystem, resident human mammary fibroblasts acquire TGF- $\beta$ and CXCL12 -mediated autocrine signaling loops, that gradually increases their tumor-promoting abilities (Kojima et al., 2010). TGF- $\beta$ mediates the transition from fibroblasts into myofibroblasts and is, by this way, a stimulator of invasion (Casey et al., 2008). In a murine model of mammary carcinogenesis, oxidative stress, with production of ROS, increased the transition of fibroblasts into myofibroblasts through downregulation of junD with upregulation of HIF-1 $\alpha$ and CXCL12 and, so, potentiated metastasis (Toullec et al., 2010). In human HER2/neu-positive tumors nuclear exclusion of junD was associated with a high proportion of myofibroblasts, senescenceassociated pro-inflammatory cytokine secretion, characterized by IL- 6 and IL- 8 and a higher nodal status. Senescent fibroblasts turn premalignant cells into fully transformed invasive cancer cells (Parrinello et al., 2005).

Stromal fibroblasts may also counteract the tumor. Targeted genetic inactivation of PTEN encoding a tumor suppressor phosphatase, in resident tissue fibroblasts of mouse mammary glands accelerated the initiation and progression of ErbB2-driven mammary epithelial tumors, characterized by massive accumulation of collagen type I and infiltration of F4/80-positive macrophages (Trimboli et al., 2009). Using such tumor-suppressor PTENmouse model for co-evolution of tumor and stroma, Wallace et al. (2010) distinguish between 5 types of breast cancer (Basal; HER2-positive/ ER-negative; Normal-like; Luminal A; Luminal B) combined with 5 stromal subtypes.

In the developing mammary gland, senescent fibroblasts disrupt epithelial alveolar morphogenesis, functional differentiation and branching morphogenesis (Parrinello et al., 2005). Using reciprocal transplantation in transgenic mice and in vitro recombination of mammary cells, Vaught et al. (2009) put forward a scenario in which SF/HGF produced by mesenchymal stroma and binding to their c-MET receptor on epithelial cells interacts with EphA 2 receptor tyrosine kinase on the epithelial cells leading to downregulation of the small GTPase RhoA and to branching morphogenesis.

\section{Adipocytes and the mammary fat pad}

The mammary fat pad, the stromal compartment of the mammary gland, is rich in adipocytes. The latter are vital for the development of the mammary gland as reviewed by Hovey and Aimo (2010). Local cancer cell invasion or branching of the normal gland inevitably brings the epithelium in contact with adipocytes. Like CAFs, cancer-associated adipocytes exert pro-invasive activities (Tan et al., 2011b); there are arguments to accept that adipose tissue-derived stem cells generate CAFs and that this process is stimulated by breast cancer cells (Jotzu et al., 2010). Coculture of such cancer cells with mature adipocytes increased invasion of cancer cells and altered the adipocyte phenotype, characterized by overexpression of proteases, including MMP-11, and proinflammatory cytokines. A prominent proinvasive role is attributed to IL-6 as evidenced by its promigratory activity in vitro and its association with lymph node metastasis in human cancers (Walter et al., 2009; Dirat et al., 2010).

\section{Nerve cells, afferent and efferent pathways}

Afferent signals, from the tumor to the nerve cells, evoke pain and stimulate neurogenesis; efferent signals, from the nerve to the tumor, such as endothelin and prostaglandins, stimulate inflammation, angiogenesis and invasion (Manthy et al., 2002). Perineural invasion is a pathological manifestation of this mutual interaction; it indicates worse prognosis in cancers of the prostate, amongst others. In breast cancer perineural invasion is rare, as it occurs in about $1 \%$ of the cases; it has no proven prognostic value in multivariate analysis (Karak et al., 2010; Cosar et al., 2011; Yenidunya et al., 2011).

\section{Osteoblasts/osteoclasts and bone metastases}

The ecosystem of bone metastasis with osteoblasts and osteoclasts as key cellular players, is probably the one that has been worked out in most detail; it is a succesful target for both systemic and local treatment, as discussed in a previous Special Issue (Vakaet and Boterberg, 2004). Since, novel molecular players have been added to the list. For example, PIGF, an homologue of VEGF-A, is released by osteogenic cells and this is enhanced by breast cancer cells metastatic to bone. Anti-mouse PIGF inhibits both homing of cancer cells in the bone and progression of bone metastases, without affecting angiogenesis (Coenegrachts et al., 2010). Gamma-secretase, a transmembrane multi-subunit protease complex, plays a critical role in the inhibition of osteoblast differentiation, in stimulation of osteoblast-dependent osteoclast differentiation and, as a consequence, in enhancement of attachment of breast cancer cells to bone cells in cocultures (Fong et al., 2010). The chemokines IL-6, monocyte chemoattractant protein-1 (MCP-1), VEGF, macrophage inflammatory protein-2 (MIP-2) and keratinocyte-derived chemokine (KC) are produced by osteoblasts in higher amounts when breast cancer cells are present (Bussard et al., 2010).

\section{Communication between distant ecosystems}

The relationship between the primary tumor and the sites of metastasis is not limited to the abovementioned multistep invasion process of cancer cells, that leave their site of origin and home at distant sites. It also implicates stromal cells traveling from the bone marrow to the primary tumor and to sites of metastasis upon signals that are released from these sites into the circulation and captured in the bone marrow or in the lymph nodes. To be added to the communicating ecosystems in breast are endocrine organs and the liver (Fig. 5).

The relatively novel concept of the pre-metastatic niche describes alterations in the site of metastasis before the arrival of the cancer cells.

\section{Which signals evoke these alterations?}

Lymph nodes are probably the first site where signals from the tumor, namely tumor antigens, are received. For breast cancer, sentinel lymph nodes are considered as the earlier step in metastasis. There is ample evidence to accept that cancer cells are armored for metastasis, meaning that cancer cells acquire specialized functions to home and grow in particular organs, such as lymph nodes, bone, brain, etc. Using subpopulations of breast cancer cell lines and human cancers, metastatic or not, several authors have found profiles with genes encoding proteins that serve organ-specific metastasis. These profiles are different from poor prognosis profiles as evidenced by the bone metastasis signature in xenografted 
subclones from a pleural metastasis and confirmed by a retrospective analysis of primary tumors that did or didn't metastasize to the bone (Minn et al., 2005).

Some metastasis-associated molecules operate in normal "metastatic" cells, such as the CD73 transmembrane protein expressed in MDA-MB-435 variants selected for lymph node metastasis and implicated in the normal lymphocyte homing process (Lee et al., 2003). Others are expressed only at the site of metastasis and co-opted by breast cancer cells. Gene expression analysis plus functional tests of cells isolated from brain metastases put forward COX2, heparin-binding EGF-like growth factor, a ligand for EGFR, and the sialyltransferase ST6GALNAC5, as mediators of extravasation through non-fenestrated capillaries, specific enhancers of blood-brain barrier crossing and brain colonization (Bos etal., 2009).

In the 4T1 syngeneic mouse breast tumor, the BCL-2 binding protein BNIP3, a mediator of hypoxia-induced cell death, proved to be a negative regulator of metastasis (Manka et al., 2005). Hypoxiainduced Bnip3 expression was lowest in highly metastatic cells, intermediate in disseminating but nonmetastatic cells, i.e. cells that circulate and home to lungs but rapidly disappear. Downregulation of Bnip3 in these cells enabled them to metastasize to lungs, liver and sternum and this correlated with increase of cleaved caspase-3.

\section{Which cells participate at the niche formation?}

Sites of putative metastasis, also called destination or designated organs, undergo changes that prime the soil to receive incoming cancer cells.. BM-derived HPCs are operative in creating such a receptive ecosystem (Kaplan et al., 2005; Hiratsuka et al., 2006; Psaila et al., 2006-2007). These authors agree that VEGFR-1-positive HPCs arrive before the cancer cells whereas VEGFR-2-positive EPCs come together with cancer cells. Other authors, using B16 melanoma and LLC lung models, doubt about the moment at which the niche cells arrive at the site of metastasis. They found that VEGFR-1-positive myeloid cells infiltrate in growing lung metastases but are not required for spontaneous metastasis formation as induced by surgical removal of the primary tumor. VEGF-1 blockade does not modulate infiltration of CD11b-positive BMDCs prior to metastasis formation; it does so, however, at later time points (Dawson et al., 2009). A sequential scenario was proposed for primary tumors and distant metastases by Hiratsuka et al. (2011a) : smaller tumors recruit Gr-1-positive myeloid BMDCs using the CXCL12/CXCR4 pathway to activate p38MAPK; then, established tumors recruit macrophages by activation of VEGFR1- and p38MAPK in these BMDCs. In the lung, TAMs come from resident pools or from the BM. BMDCs that home in the perivascular zone amplify angiogenesis in both the primary tumor and the metastasis; and they comprise: F4/80-positive/CD11b- negative macrophages; VEGFR-positive/CXCR4-positive/CD11b- negative myeloid cells; CD11b-positive/Tie-2-positive monocytes; VEGFR-positive/CXCR4negative hemangiocytes; CD11b-positive/VE-cadherin- negative vascular leucocytes, Gr1-positiv/CD11b-positive neutrophils; MDSCs (Kerbel, 2008). Differences between ecosystems were described for 4T1 tumor-bearing mice having myeloid cell, mostly CD11b-positive, infiltrates in the primary tumor and granulocytic (Gr-1-positive) infiltrates in metastatic organs (DuPré et al., 2007) . The fact that BMDCs contributing to the formation of a premetastatic niche have their natural habitat in the bone marrow might explain the high tendency of cancer cells, including breast cancer, to home and develop metastases in the bone.

\section{How does the niche attract metastatic cancer cells?}

Cytokines and their receptors implicated in the communication

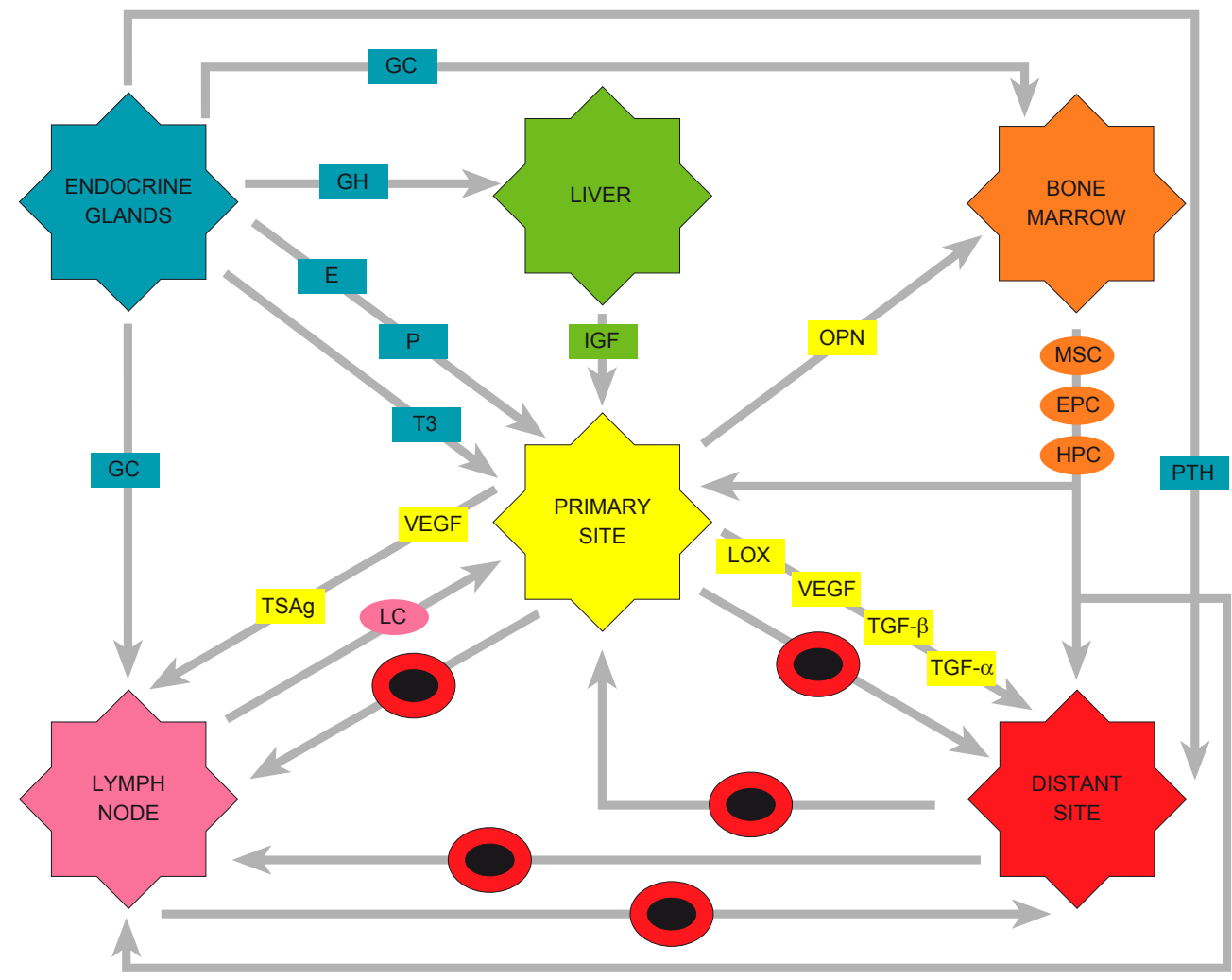

Fig. 5. Interactions between ecosystems participating at metastatic cancer with sites of primary tumor, distant metastasis and lymph node metastasis, and with organs, endocrine glands, liver and bone marrow producing cells and molecules targetting tumor sites. Red spheres are metastatic cancer cells; orange spheres are bone marrow-derived cells, namely: MSC, mesenchymal stem cells; EPC, endothelial precursor cells; $H P C$, hematopoietic precursor cells. LC, lymphoid cells. E, estrogen; GC, glucocorticoids; $H G$, growth hormone; IGF, insuline-like growth factor; LOX, lysyl oxidase; OPN, osteopontin; P, progesteron; PTH, parathyroid hormone; T3, triiodothyronine; TGF- $\beta$, transforming growth factor-beta; TNF- $\alpha$, tumor necrosis factor-alpha; TSAg, tumor specific antigen; VEGF, vascular endothelial growth factor Data from: Elkabets et al. (2010); Kaplan et al. (2006); Erler et al. (2009); Dupre et al. (2007); Hiratsuka et al. (2006); Psaila et al. (2006-2007); Hiratsuka et al. (2011a); Perry et al. (2008); Quante et al. (2011). 

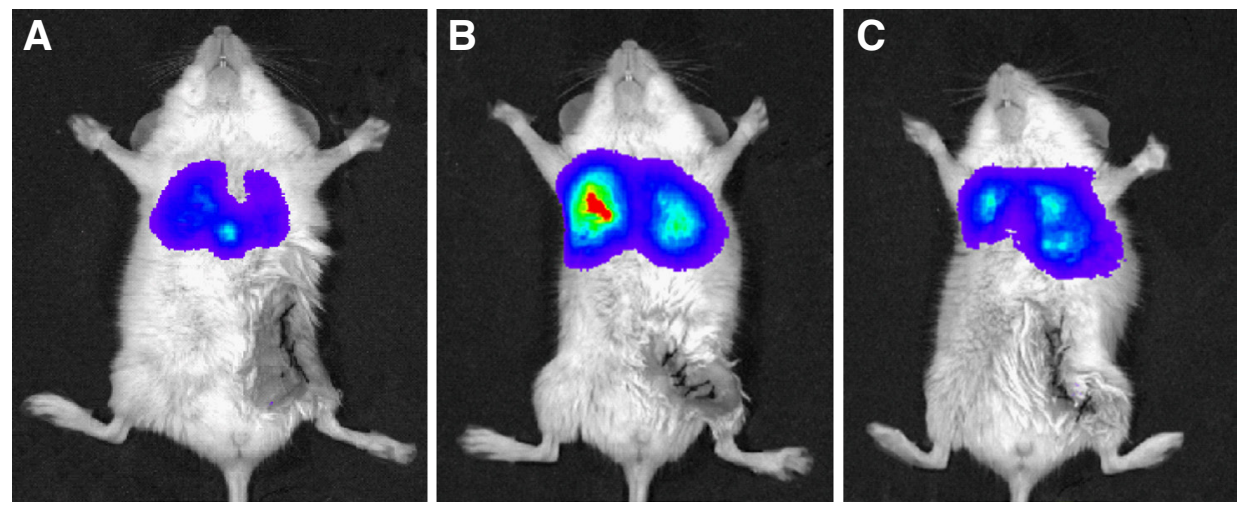

Fig. 6. Bioimaging of lung metastases in mice 20 days after injection with $\mathbf{4 T} 1$ cancer cells into the left mammary fat pad. Mice were left untreated (A), irradiated with $0.3 \mathrm{~Gy}(\mathbf{B})$ or irradiated with 0.3 Gy plus injection with the antiangiogenic agent PTK/ZK (C) 22 hours before injection of the cancer cells. Primary tumors were removed before imaging. Details of the experiments are described in Vala et al. (2010)

between primary tumor, BM and premetastatic niche are tabulated in Kaplan et al. (2006). Osteopontin is put forward in the systemic instigation model in which endocrine signals are sent from certain tumors (instigators) to stimulate BM cells, which are mobilized into the circulation and subsequently foster the growth of otherwise indolent carcinoma cells (responders) residing at distant anatomical sites (Elkabets et al., 2010). These BMDCs are Sca1-positive/ cKitnegative/CD45-positive and the most upregulated gene is granulin . In human breast cancer, high granulin expression correlates with more aggressive triple-negative, basal-like tumor subtype. Disseminated tumor factors, VEGF, TNF- $\alpha$, TGF- $\beta$ and possibly others elicit an inflammatory state that accelerates recruitment of cancer cells to the premetastatic niche. Here, production of the calcium-binding proteins S100A8 and S100A9 induce the expression of serum amyloid SAA3 promoting recruitement of Mac1-positive myeloid cells and endothelial cells (Hiratsuka et al., 2008; Peinado et al., 2008). Although disseminated factors are supposed to affect distant organs in a difuse way, metastases develop as a series of discrete lesions, as demonstrated in E0771 syngeneic mouse mammary cancer (Hiratsuka et al., 2011b). Such lesions correspond with the induction of discrete foci of vascular hyperpermeability in premetastatic lungs. VEGF and other factors in the conditioned medium of cancer cells activate FAK and higher pFAK in areas of conditioned medium-induced hyperpermeability are associated with E-selectin responsible for cancer cell homing through adhesion to lung endothelium. LOX is secreted by hypoxic cells at the primary tumor and accumulates at sites of distant metastasis, where it crosslinks collagen IV, increasing adhesion of CD11b-positive myeloid cells and causing them to secrete MMP-2, a.o. MMPs (Erler JT, 2009). LOX-mediated recruitement of CD11b-positive myeloid cells may also downregulate immune T-cell responses (Erler et al., 2006) .

Development of the normal mammary gland is modulated mainly through interaction with endocrine glands. Hormones involved in this modulation also affect breast cancer and are of prime importance in treatment.

In contrast with cancer, spread of epithelial cells through the vasculature is a rare event during embryogenesis. Cells that leave their site of origin to home throughout the body as observed with neural crest cells , migrate through the tissues and are not transported by the circulation (Duband, 2006). A remarkable exception phamide (Farmer et al. 2009). Markers for pre-and pertreatment imaging are needed to monitor the therapy and such markers might be found not only in the cancer cells but also in the stromal elements of the tumor (Fleming et al., 2010). The challenge is to define the ecosystem at one time in order to estimate what would happen at later times and then design the treatment in consequence.

Two. New insights into the ecosystem and analysis of its elements may provide new targets for therapy. The finding that resection of the primary tumor improves the prognosis in advanced breast cancer fits with the cancer stem cell niche theory( Zhang $\mathrm{N}$ and Yang Q, 2009). The paradigm of stromal cell targetting drugs are bisphosphonates, inhibitors of osteoclasts that are successfully used for the treatment of bone metastases. Selected examples of new targetted drugs under preclinical and clinical testing are tabulated in Bissell and Hines (2011). Inhibitors of angiogenesis, such as the VEGF antibody bevasizumab (Delli Carpini et al., 2010), have been most widely applied as reviewed in Dome et al. (2007). Surprisingly, anti-angiogenic agents may promote invasive tumor growth and distant metastasis, a phenomenon termed adaptive-evasive response (Paeze-Ribes et al., 2009). Hormetic dose-responses, producing bell-shaped or U-shaped in stead of sigmoidal curves, may explain this therapeutic failure (Reynolds, 2010). CAFs present another target as reviewed by De Wever et al. (2008). Macrophages are induced into apoptosis by a low inoculum of an attenuated strain of Shigella flexneri and this counteracts the progression of a transgenic mouse breast cancer (Galmbacher et al., 2010).

Three. Current forms of therapy, surgery, chemotherapy, endocrine therapy and radiotherapy, may stimulate invasion and metastasis through effects on the cancer cells but also on the other elements of the ecosystem, as reviewed by Madani et al., (2008) and by Ceelen and Bracke (2009). More recent publications have confirmed these observations, providing one possible explanation why advances in locoregional disease control are not followed by decrease in distant metastasis (Vala et al., 2010; De Bacco et al., 2011). An example is given in Fig. 6 .

\section{Conclusions}

Breast cancer, like other metastatic cancers, can be considered as a collection of interacting ecosystems implicating hundreds of 
molecules and their signalling pathways, tens of kinds of cells of the same and of different types and origins, and several sites in the body. These ecosystems resemble, yet must crucially differ, from the ones found in the developing mammary gland. There is experimental and clinical evidence to accept that manipulation of single elements in these ecosystems may change the course of the entire disease. The challenge is to find the key elements that distinguish between normal and cancer and that may be tested as targets for therapy.

\section{Acknowledgments \\ The authors thank Georges De Bruyne and Dieter Berwouts for help with figures and references.}

\section{References}

ABOUSSEKHRA, A. (2011) Role of cancer-associated fibroblasts in breast cancer development and prognosis. Int. J. Dev. Biol. 55: 841 - 849. (DOI: 10.1387/ ijdb.113362aa)

ABRAHAM, B.K., FRITZ, P., MCCLELLAN, M., HAUPTVOGEL, P., ATHELOGOU, M. and BRAUCH, H. (2005). Prevalence of CD44+/CD24-/low cells in breast cancer may not be associated with clinical outcome but may favor distant metastasis. Clin Cancer Res 11: 1154-1159.

ALI, S. and LAZENNEC, G. (2007). Chemokines: novel targets for breast cancer metastasis. Cancer Metastasis Rev 26: 401-420.

BANERJEE, S., LIN, C.F., SKINNER, K.A., SCHIFFHAUER, L.M., PEACOCK, J., HICKS, D.G., REDMOND, E.M., MORROW, D., HUSTON, A., SHAYNE, M. et al. (2011). Heat shock protein 27 differentiates tolerogenic macrophages that may support human breast cancer progression. Cancer Res 71: 318-327.

BASSET, P., BELLOCQ, J.P., WOLF, C., STOLL, I., HUTIN, P., LIMACHER, J.M., PODHAJCER, O.L., CHENARD, M.P., RIO, M.C. and CHAMBON, P. (1990). A novel metalloproteinase gene specifically expressed in stromal cells of breast carcinomas. Nature 348: 699-704.

BELLAIRS, R. (1971) Developmental processes in higher vertebrates. Logos Press Limited.

BERX, G. and VAN ROY, F. (2001). The E-cadherin/catenin complex: an important gatekeeper in breast cancer tumorigenesis and malignant progression. Breast Cancer Res 3: 289-293.

BIDARD, F.C., PIERGA, J.Y., VINCENT-SALOMON, A. and POUPON, M.F. (2008). A "class action" against the microenvironment: do cancer cells cooperate in metastasis? Cancer Metastasis Rev 27: 5-10.

BISSELL, M.J. and HINES, W.C. (2011). Why don't we get more cancer? Aproposed role of the microenvironment in restraining cancer progression. Nat Med 17: 320-329.

BOHLING, S.D. and ALLISON, K.H. (2008). Immunosuppressive regulatory T cells are associated with aggressive breast cancer phenotypes: a potential therapeutic target. Mod Pathol 21: 1527-1532.

BOS, P.D., ZHANG, X.H., NADAL, C., SHU, W., GOMIS, R.R., NGUYEN, D.X., MINN, A.J., VAN DE VIJVER, M.J., GERALD, W.L., FOEKENS, J.A. et al. (2009). Genes that mediate breast cancer metastasis to the brain. Nature 459: 1005-1009.

BUSSARD, K.M., VENZON, D.J. and MASTRO, A.M. (2010). Osteoblasts are a major source of inflammatory cytokines in the tumor microenvironment of bone metastatic breast cancer. J Cell Biochem 111: 1138-1148.

CAMPBELL, M.J., TONLAAR, N.Y., GARWOOD, E.R., HUO, D., MOORE, D.H., KHRAMTSOV, A.I., AU, A., BAEHNER, F., CHEN, Y., MALAKA, D.O. et al. (2010). Proliferating macrophages associated with high grade, hormone receptor negative breast cancer and poor clinical outcome. Breast Cancer Res Treat.

CARPENTER, P.M. and NGUYEN, H.P. (1998). Mammary epithelium-induced motility of MCF-7 cells. Anticancer Res 18: 1063-1068.

CASEY, T.M., ENEMAN, J., CROCKER, A., WHITE, J., TESSITORE, J., STANLEY, M., HARLOW, S., BUNN, J.Y., WEAVER, D., MUSS, H. et al. (2008). Cancer associated fibroblasts stimulated by transforming growth factor beta1 (TGF-beta 1) increase invasion rate of tumor cells: a population study. Breast Cancer Res Treat 110: 39-49.

CEBE-SUAREZ, S., ZEHNDER-FJALLMAN, A. and BALLMER-HOFER, K. (2006).
The role of VEGF receptors in angiogenesis; complex partnerships. Cell Mol Life Sci 63: 601-615.

CEELEN, W.P. and BRACKE, M.E. (2009). Peritoneal minimal residual disease in colorectal cancer: mechanisms, prevention, and treatment. Lancet Oncol10:72-79.

CHANG, H.Y., NUYTEN, D.S., SNEDDON, J.B., HASTIE, T., TIBSHIRANI, R., SORLIE, T., DAI, H., HE, Y.D., VAN'T VEER, L.J., BARTELINK, H. et al. (2005). Robustness, scalability, and integration of a wound-response gene expression signature in predicting breast cancer survival. Proc Natl Acad Sci U S A 102: 3738-3743.

COENEGRACHTS, L., MAES, C., TORREKENS, S., VAN LOOVEREN, R., MAZZONE, M., GUISE, T.A., BOUILLON, R., STASSEN, J.M., CARMELIET, P. and CARMELIET, G. (2010). Anti-placental growth factor reduces bone metastasis by blocking tumor cell engraftment and osteoclast differentiation. Cancer Res 70: 6537-6547.

CONDEELIS, J. and POLLARD, J.W. (2006). Macrophages: obligate partners for tumor cell migration, invasion, and metastasis. Cell 124: 263-266.

COSAR, R., UZAL, C., TOKATLI, F., DENIZLI, B., SAYNAK, M., TURAN, N., UZUNOGLU, S., OZEN, A., SEZER, A., IBIS, K. et al. (2011). Postmastectomy irradiation in breast in breast cancer patients with $\mathrm{T} 1-2$ and 1-3 positive axillary lymph nodes: Is there a role for radiation therapy? Radiat Oncol 6: 28 .

DADIANI, M., SEGER, D., KREIZMAN, T., BADIKHI, D., MARGALIT, R., EILAM, R. and DEGANI, H. (2009). Estrogen regulation of vascular endothelial growth factor in breast cancer in vitro and in vivo: the role of estrogen receptor alpha and C-Myc. Endocr Relat Cancer 16: 819-834.

DAWSON, M.R., DUDA, D.G., CHAE, S.S., FUKUMURA, D. and JAIN, R.K. (2009). VEGFR1 activity modulates myeloid cell infiltration in growing lung metastases but is not required for spontaneous metastasis formation. PLoS One 4: e6525.

DE BACCO, F., LURAGHI, P., MEDICO, E., REATO, G., GIROLAMI, F., PERERA, T., GABRIELE, P., COMOGLIO, P.M. and BOCCACCIO, C. (2011). Induction of MET by lonizing Radiation and Its Role in Radioresistance and Invasive Growth of Cancer. J Natl Cancer Inst 103: 645-661.

DE WEVER, O., DEMETTER, P., MAREEL, M. and BRACKE, M. (2008). Stromal myofibroblasts are drivers of invasive cancer growth. Int J Cancer 123:2229-2238.

DELLI CARPINI, J., KARAM, A.K. and MONTGOMERY, L. (2010). Vascular endothelial growth factor and its relationship to the prognosis and treatment of breast, ovarian, and cervical cancer. Angiogenesis 13: 43-58.

DENARDO, D.G., BARRETO, J.B., ANDREU, P., VASQUEZ, L., TAWFIK, D., KOLHATKAR, N. and COUSSENS, L.M. (2009). CD4(+) T cells regulate pulmonary metastasis of mammary carcinomas by enhancing protumor properties of macrophages. Cancer Cell 16: 91-102.

DIRAT, B., BOCHET, L., ESCOURROU, G., VALET, P. and MULLER, C. (2010). Unraveling the obesity and breast cancer links: a role for cancer-associated adipocytes? Endocr Dev 19: 45-52.

DJONOV, V., ANDRES, A.C. and ZIEMIECKI, A. (2001). Vascular remodelling during the normal and malignant life cycle of the mammary gland. Microsc Res Tech 52: $182-189$.

DOME, B., HENDRIX, M.J., PAKU, S., TOVARI, J. and TIMAR, J. (2007). Alternative vascularization mechanisms in cancer: Pathology and therapeutic implications. Am J Pathol 170: 1-15.

DREWS, U. (1977). Regression of mouse mammary gland anlagen in recombinants of Tfm and wild-type tissues: testosterone acts via the mesenchyme. Cell10:401-404.

DUAN, L., CHEN, G., VIRMANI, S., YING, G., RAJA, S.M., CHUNG, B.M., RAINEY, M.A., DIMRI, M., ORTEGA-CAVA, C.F., ZHAO, X. et al. (2010). Distinct roles for Rho versus Rac/Cdc42 GTPases downstream of Vav2 in regulating mammary epithelial acinar architecture. J Biol Chem 285: 1555-1568.

DUBAND, J.L. (2006). Neural crest delamination and migration: integrating regulations of cell interactions, locomotion, survival and fate. Adv Exp Med Biol 589: 45-77.

DUPRE, S.A., REDELMAN, D. and HUNTER, K.W., JR. (2007). The mouse mammary carcinoma 4T1: characterization of the cellular landscape of primary tumours and metastatic tumour foci. Int J Exp Pathol 88: 351-360.

EGEBLAD, M., EWALD, A.J., ASKAUTRUD, H.A., TRUITT, M.L., WELM, B.E., BAINBRIDGE, E., PEETERS, G., KRUMMEL, M.F. and WERB, Z. (2008). Visualizing stromal cell dynamics in different tumor microenvironments by spinning disk confocal microscopy. Dis Model Mech 1: 155-167; discussion 165.

ELKABETS, M., RIBEIRO, V.S., DINARELLO, C.A., OSTRAND-ROSENBERG, S., DI SANTO, J.P., APTE, R.N. and VOSSHENRICH, C.A. (2010). IL-1beta regulates a novel myeloid-derived suppressor cell subset that impairs NK cell development 
and function. Eur J Immunol 40: 3347-3357.

ELLIS, L.M. and HICKLIN, D.J. (2008). VEGF-targeted therapy: mechanisms of antitumour activity. Nat Rev Cancer 8: 579-591.

ERLER, J.T., BENNEWITH, K.L., COX, T.R., LANG, G., BIRD, D., KOONG, A., LE, Q.T. and GIACCIA, A.J. (2009). Hypoxia-induced lysyl oxidase is a critical mediator of bone marrow cell recruitment to form the premetastatic niche. Cancer Cell 15: 35-44.

ERLER, J.T., BENNEWITH, K.L., NICOLAU, M., DORNHOFER, N., KONG, C., LE, Q.T., CHI, J.T., JEFFREY, S.S. and GIACCIA, A.J. (2006). Lysyl oxidase is essential for hypoxia-induced metastasis. Nature 440: 1222-1226.

EWALD, A.J., BRENOT, A., DUONG, M., CHAN, B.S. and WERB, Z. (2008). Collective epithelial migration and cell rearrangements drive mammary branching morphogenesis. Dev Cell 14: 570-581.

FARMER, P., BONNEFOI, H., ANDERLE, P., CAMERON, D., WIRAPATI, P., BECETTE, V., ANDRE, S., PICCART, M., CAMPONE, M., BRAIN, E. et al. (2009). A stromarelated gene signature predicts resistance to neoadjuvant chemotherapy in breast cancer. Nat Med 15: 68-74.

FATA, J.E., MORI, H., EWALD, A.J., ZHANG, H., YAO, E., WERB, Z. and BISSELL, M.J. (2007). The MAPK(ERK-1,2) pathway integrates distinct and antagonistic signals from TGFalpha and FGF7 in morphogenesis of mouse mammary epithelium. Dev Biol 306: 193-207.

FATA, J.E., WERB, Z. and BISSELL, M.J. (2004). Regulation of mammary gland branching morphogenesis by the extracellular matrix and its remodeling enzymes. Breast Cancer Res 6: 1-11.

FIDLER, I.J. and POSTE, G. (2008). The "seed and soil" hypothesis revisited. Lancet Oncol 9: 808.

FINAK, G., BERTOS, N., PEPIN, F., SADEKOVA, S., SOULEIMANOVA, M., ZHAO, H., CHEN, H., OMEROGLU, G., METERISSiAN, S., OMEROGLU, A. et al. (2008). Stromal gene expression predicts clinical outcome in breast cancer. Nat Med 14: 518-527.

FLEMING, I.N., GILBERT, F.J., MILES, K.A. and CAMERON, D. (2010). Opportunities for PET to deliver clinical benefit in cancer: breast cancer as a paradigm. Cancer imaging : the official publication of the International Cancer Imaging Society 10: 144-152.

FONG, J.E., LE NIHOUANNEN, D. and KOMAROVA, S.V. (2010). Tumor-supportive and osteoclastogenic changes induced by breast cancer-derived factors are reversed by inhibition of \{gamma\}-secretase. J Biol Chem 285: 31427-31434.

FRIEDL, P. and GILMOUR, D. (2009). Collective cell migration in morphogenesis, regeneration and cancer. Nat Rev Mol Cell Biol 10: 445-457.

GABBIANI, G., RYAN, G.B. and MAJNE, G. (1971). Presence of modified fibroblasts in granulation tissue and their possible role in wound contraction. Experientia 27: $549-550$.

GALMBACHER, K., HEISIG, M., HOTZ, C., WISCHHUSEN, J., GALMICHE, A., BERGMANN, B., GENTSCHEV, I., GOEBEL, W., RAPP, U.R. and FENSTERLE, J. (2010). Shigella mediated depletion of macrophages in a murine breast cancer model is associated with tumor regression. PLoS One 5: e9572.

GOBERT, M., TREILLEUX, I., BENDRISS-VERMARE, N., BACHELOT, T., GODDARD-LEON, S., ARFI, V., BIOTA, C., DOFFIN, A.C., DURAND, I., OLIVE, D. et al. (2009). Regulatory T cells recruited through CCL22/CCR4 are selectively activated in lymphoid infiltrates surrounding primary breast tumors and lead to an adverse clinical outcome. Cancer Res 69: 2000-2009.

GRIVENNIKOV, S.I. and KARIN, M. (2010). Dangerous liaisons: STAT3 and NFkappaB collaboration and crosstalk in cancer. Cytokine Growth Factor Rev21:11-9.

GUAN, J.L. (2010). Integrin signaling through FAK in the regulation of mammary stem cells and breast cancer. IUBMB Life 62: 268-276.

GUARINO, M., RUBINO, B. and BALLABIO, G. (2007). The role of epithelial-mesenchymal transition in cancer pathology. Pathology 39: 305-318.

HAENSSEN, K.K., CALDWELL, S.A., SHAHRIARI, K.S., JACKSON, S.R., WHELAN, K.A., KLEIN-SZANTO, A.J. and REGINATO, M.J. (2010). ErbB2 requires integrin alpha5 for anoikis resistance via Src regulation of receptor activity in human mammary epithelial cells. J Cell Sci 123: 1373-1382.

HAGEMANN, T., WILSON, J., KULBE, H., LI, N.F., LEINSTER, D.A., CHARLES, K., KLEMM, F., PUKROP, T., BINDER, C. and BALKWILL, F.R. (2005). Macrophages induce invasiveness of epithelial cancer cells via NF-kappa B and JNK. $J$ Immunol 175: 1197-1205.

HAMMOND, S.L., HAM, R.G. and STAMPFER, M.R. (1984). Serum-free growth of hu- man mammary epithelial cells: rapid clonal growth in defined medium and extended serial passage with pituitary extract. Proc Natl Acad Sci U S A 81: 5435-5439.

HARFOUCHE, R., ECHAVARRIA, R., RABBANI, S.A., ARAKELIAN, A., HUSSEIN, M.A. and HUSSAIN, S.N. (2011). Estradiol-dependent regulation of angiopoietin expression in breast cancer cells. J Steroid Biochem Mol Biol 123: 17-24.

HATSELL, S., ROWLANDS, T., HIREMATH, M. and COWIN, P. (2003). Beta-catenin and Tcfs in mammary development and cancer. J Mammary Gland Biol Neoplasia 8: 145-158.

HEMBRUFF, S.L., JOKAR, I., YANG, L. and CHENG, N. (2010). Loss of transforming growth factor-beta signaling in mammary fibroblasts enhances CCL2 secretion to promote mammary tumor progression through macrophage-dependent and -independent mechanisms. Neoplasia 12: 425-433.

HENNESSY, B.T., GONZALEZ-ANGULO, A.M., STEMKE-HALE, K., GILCREASE, M.Z., KRISHNAMURTHY, S., LEE, J.S., FRIDLYAND, J., SAHIN, A., AGARWAL, R., JOY, C. et al. (2009). Characterization of a naturally occurring breast cancer subset enriched in epithelial-to-mesenchymal transition and stem cell characteristics. Cancer Res 69: 4116-4124.

HEUBERGER, B., FITZKA, I., WASNER, G. and KRATOCHWIL, K. (1982). Induction of androgen receptor formation by epithelium-mesenchyme interaction in embryonic mouse mammary gland. Proc Natl Acad Sci U S A 79: 2957-2961.

HILAKIVI-CLARKE, L. and DEASSIS, S. (2006). Fetal origins of breast cancer. Trends Endocrinol Metab 17: 340-348.

HIRATSUKA, S., DUDA, D.G., HUANG, Y., GOEL, S., SUGIYAMA, T., NAGASAWA T., FUKUMURA, D. and JAIN, R.K. (2011a). C-X-C receptor type 4 promotes metastasis by activating p38 mitogen-activated protein kinase in myeloid differentiation antigen (Gr-1)-positive cells. Proc Natl Acad Sci U S A 108: 302-307.

HIRATSUKA, S., GOEL, S., KAMOUN, W.S., MARU, Y., FUKUMURA, D., DUDA, D.G. and JAIN, R.K. (2011b). Endothelial focal adhesion kinase mediates cancer cell homing to discrete regions of the lungs via E-selectin up-regulation. Proc Natl Acad Sci U S A 108: 3725-3730.

HIRATSUKA, S., WATANABE, A., ABURATANI, H. and MARU, Y. (2006). Tumourmediated upregulation of chemoattractants and recruitment of myeloid cells predetermines lung metastasis. Nature Cell Biol 8: 1369-1375.

HIRATSUKA, S., WATANABE, A., SAKURAI, Y., AKASHI-TAKAMURA, S., ISHIBASHI, S., MIYAKE, K., SHIBUYA, M., AKIRA, S., ABURATANI, H. and MARU, Y. (2008). The S100A8-serum amyloid A3-TLR4 paracrine cascade establishes a pre-metastatic phase. Nat Cell Biol 10: 1349-1355.

HODGES, G. and ROWLATT, C. Eds. (1994). Developmental Biology and Cancer. CRC Press, Inc.

HOU, Z., FALCONE, D.J., SUBBARAMAIAH, K. and DANNENBERG, A.J. (2011) Macrophages induce COX-2 expression in breast cancer cells: role of IL-1\{beta\} autoamplification. Carcinogenesis 32: 695-702.

HOVEY, R.C. and AIMO, L. (2010). Diverse and active roles for adipocytes during mammary gland growth and function. JMammary Gland Biol Neoplasia 15:279-90.

HYDER, S.M., LIANG, Y. and WU, J. (2009a). Estrogen regulation of thrombospondin-1 in human breast cancer cells. Int J Cancer 125: 1045-1053.

HYDER, S.M., LIANG, Y., WU, J. and WELBERN, V. (2009b). Regulation of thrombospondin-1 by natural and synthetic progestins in human breast cancer cells. Endocr Relat Cancer 16: 809-817.

IIIZUMI, M., BANDYOPADHYAY, S. and WATABE, K. (2007). Interaction of Duffy antigen receptor for chemokines and KAI1: a critical step in metastasis suppression. Cancer Res 67: 1411-1414.

ISLAM, M.S., MATSUMOTO, M., ISHIDA, R., OKA, T. and KANOUCHI, H. (2010). Change in VEGF expression in mouse mammary gland during reproductive cycle. $J$ Vet Med Sci 72: 1159-1163.

JOTZU, C., ALT, E., WELTE, G., LI, J., HENNESSY, B.T., DEVARAJAN, E., KRISHNAPPA, S., PINILLA, S., DROLL, L. and SONG, Y.H. (2010). Adipose tissue-derived stem cells differentiate into carcinoma-associated fibroblast-like cells under the influence of tumor-derived factors. Anal Cell Pathol (Amst) 33: 61-79.

JOUANNEAU, J., MOENS, G., BOURGEOIS, Y., POUPON, M.F. and THIERY, J.P. (1994). A minority of carcinoma cells producing acidic fibroblast growth factor induces a community effect for tumor progression. Proc Natl Acad Sci U S A 91: $286-290$

KALLURI, R. and WEINBERG, R.A. (2009). The basics of epithelial-mesenchymal transition. J Clin Invest 119: 1420-1428.

KAPLAN, R.N., RAFII, S. and LYDEN, D. (2006). Preparing the "soil": the premetastatic 
niche. Cancer Res 66: 11089-11093.

KAPLAN, R.N., RIBA, R.D., ZACHAROULIS, S., BRAMLEY, A.H., VINCENT, L., COSTA, C., MACDONALD, D.D., JIN, D.K., SHIDO, K., KERNS, S.A. et al (2005). VEGFR1-positive haematopoietic bone marrow progenitors initiate the pre-metastatic niche. Nature 438: 820-827.

KARAK, S.G., QUATRANO, N., BUCKLEY, J. and RICCI, A., JR. (2010). Prevalence and significance of perineural invasion in invasive breast carcinoma. Conn Med 74: 17-21.

KASS, L., ERLER, J.T., DEMBO, M. and WEAVER, V.M. (2007). Mammary epithelial cell: influence of extracellular matrix composition and organization during development and tumorigenesis. Int J Biochem Cell Biol 39: 1987-1794.

KATZ, E. and STREULI, C.H. (2007). The extracellular matrix as an adhesion checkpoint for mammary epithelial function. Int J Biochem Cell Biol 39: 715-26.

KERBEL, R.S. (2008). Tumor angiogenesis. The New England journal of medicine 358: 2039-2049.

KOJIMA, Y., ACAR, A., EATON, E.N., MELLODY, K.T., SCHEEL, C., BEN-PORATH, I., ONDER, T.T.,

WANG, Z.C., RICHARDSON, A.L., WEINBERG, R.A. et al. (2010). Autocrine TGFbeta and stromal cell-derived factor-1 (SDF-1) signaling drives the evolution of tumor-promoting mammary stromal myofibroblasts. Proc Natl Acad Sci U S A 107: 20009-20014.

KUMAR, R., VADLAMUDI, R.K. and ADAM, L. (2000). Apoptosis in mammary gland and cancer. Endocr Relat Cancer 7: 257-269.

LAOUI, D., MOVAHEDI, K., VAN OVERMEIRE, E., VAN DEN BOSSCHE, J., SCHOUPPE, E., MOMMER, C., NIKOLAOU, A., MORIAS, Y., DE BAETSELIER, P., and VAN GINDERACHTER, J.A. (2011) Tumor-associated macrophages in breast cancer: distinct subsets, distinct functions. Int. J. Dev. Biol. (DOI: $10.1387 /$ ijdb.113371dl)

LEE, H., LIN, E.C., LIU, L. and SMITH, J.W. (2003). Gene expression profiling of tumor xenografts: In vivo analysis of organ-specific metastasis. Int J Cancer 107:528-534.

LIM, E., VAILLANT, F., WU, D., FORREST, N.C., PAL, B., HART,A.H., ASSELIN-LABAT, M.L., GYORKI, D.E., WARD, T., PARTANEN, A. et al. (2009). Aberrant luminal progenitors as the candidate target population for basal tumor development in BRCA1 mutation carriers. Nat Med 15: 907-913.

LOUIE, E., NIK, S., CHEN, J.S., SCHMIDT, M., SONG, B., PACSON, C., CHEN, X.F., PARK, S., JU, J. and CHEN, E.I. (2010). Identification of a stem-like cell population by exposing metastatic breast cancer cell lines to repetitive cycles of hypoxia and reoxygenation. Breast Cancer Res 12: R94.

LUO, T., WANG, J., YIN, Y., HUA, H., JING, J., SUN, X., LI, M., ZHANG, Y. and JIANG, Y. (2010). (-)-Epigallocatechin gallate sensitizes breast cancer cells to paclitaxel in a murine model of breast carcinoma. Breast Cancer Res 12: R8.

MADANI, I., DE NEVE, W. and MAREEL, M. (2008). Does ionizing radiation stimulate cancer invasion and metastasis? Bull Cancer 95: 292-300.

MADEO, A. and MAGGIOLINI, M. (2010). Nuclear alternate estrogen receptor GPR30 mediates 17beta-estradiol-induced gene expression and migration in breast cancer-associated fibroblasts. Cancer Res 70: 6036-6046.

MAFUVADZE, B., BENAKANAKERE, I. and HYDER, S.M. (2010). Apigenin blocks induction of vascular endothelial growth factor mRNA and protein in progestintreated human breast cancer cells. Menopause 17: 1055-1063.

MANKA, D., SPICER, Z. and MILLHORN, D.E. (2005). Bcl-2/adenovirus E1B 19 kDa interacting protein-3 knockdown enables growth of breast cancer metastases in the lung, liver, and bone. Cancer Res 65: 11689-11693.

MAREEL, M., OLIVEIRA, M.J. and MADANI, I. (2009). Cancer invasion and metastasis: interacting ecosystems. Virchows Arch 454: 599-622.

MASSON, R., LEFEBVRE, O., NOEL, A., FAHIME, M.E., CHENARD, M.P., WENDLING, C., KEBERS, F., LEMEUR, M., DIERICH, A., FOIDART, J.M. et al. (1998). In vivo evidence that the stromelysin-3 metalloproteinase contributes in a paracrine manner to epithelial cell malignancy. The Journal of cell biology 140: 1535-1541.

MICALIZZI, D.S., FARABAUGH, S.M. and FORD, H.L. (2010a). Epithelial-mesenchymal transition in cancer: parallels between normal development and tumor progression. J Mammary Gland Biol Neoplasia 15: 117-134.

MICALIZZI, D.S., WANG, C.A., FARABAUGH, S.M., SCHIEMANN, W.P. and FORD, H.L. (2010b). Homeoprotein Six 1 increases TGF-beta type I receptor and converts TGF-beta signaling from suppressive to supportive for tumor growth. Cancer Res 70: $10371-10380$
MINN, A.J., KANG, Y., SERGANOVA, I., GUPTA, G.P., GIRI, D.D., DOUBROVIN, M., PONOMAREV, V., GERALD, W.L., BLASBERG, R. and MASSAGUE, J. (2005). Distinct organ-specific metastatic potential of individual breast cancer cells and primary tumors. J Clin Invest 115: 44-55.

MONKS, J., SMITH-STEINHART, C., KRUK, E.R., FADOK, V.A. and HENSON, P.M. (2008). Epithelial cells remove apoptotic epithelial cells during post-lactation involution of the mouse mammary gland. Biol Reprod 78: 586-594.

NAVIN, N., KENDALL, J., TROGE, J., ANDREWS, P., RODGERS, L., MCINDOO, J., COOK, K., STEPANSKY, A., LEVY, D., ESPOSITO, D. et al. (2011). Tumour evolution inferred by single-cell sequencing. Nature 472: 90-94

NICOLSON, G.L., BRUNSON, K.W. and FIDLER, I.J. (1978). Specificity of arrest, survival, and growth of selected metastatic variant cell lines. Cancer Res 38 4105-4111.

NILSSON, U.W., ABRAHAMSSON, A. and DABROSIN, C. (2010). Angiogenin regulation by estradiol in breast tissue: tamoxifen inhibits angiogenin nuclear translocation and antiangiogenin therapy reduces breast cancer growth in vivo. Clin Cancer Res 16: 3659-3669.

O'BRIEN, J., LYONS, T., MONKS, J., LUCIA, M.S., WILSON, R.S., HINES, L., MAN Y.G., BORGES, V. and SCHEDIN, P. (2010). Alternatively activated macrophages and collagen remodeling characterize the postpartum involuting mammary gland across species. Am J Pathol 176: 1241-1255.

OGBA, N., DOUGHMAN, Y.Q., CHAPLIN, L.J., HU, Y., GARGESHA, M., WATANABE M. and MONTANO, M.M. (2010). HEXIM1 modulates vascular endothelial growth factor expression and function in breast epithelial cells and mammary gland. Oncogene 29: 3639-3649.

OWENS, T.W., FOSTER, F.M., TANIANIS-HUGHES, J., CHEUNG, J.Y., BRACKENBURY, L. and STREULI, C.H. (2010). Analysis of inhibitor of apoptosis protein family expression during mammary gland development. BMC Dev Biol 10: 71.

PAEZ-RIBES, M., ALLEN, E., HUDOCK, J., TAKEDA, T., OKUYAMA, H., VINALS, F., INOUE, M., BERGERS, G., HANAHAN, D. and CASANOVAS, O. (2009). Antiangiogenic therapy elicits malignant progression of tumors to increased local invasion and distant metastasis. Cancer Cell 15: 220-231.

PARRINELLO, S., COPPE, J.P., KRTOLICA, A. and CAMPISI, J. (2005). Stromalepithelial interactions in aging and cancer: senescent fibroblasts alter epithelial cell differentiation. J Cell Sci 118: 485-496.

PAULSSON, J., SJOBLOM, T., MICKE, P., PONTEN, F., LANDBERG, G., HELDIN, C.H., BERGH, J., BRENNAN, D.J., JIRSTROM, K. and OSTMAN, A. (2009). Prognostic significance of stromal platelet-derived growth factor beta-receptor expression in human breast cancer. Am J Pathol 175: 334-341.

PEINADO, H., RAFII, S. and LYDEN, D. (2008). Inflammation joins the "niche". Cancer Cell 14: 347-349

PEPPER, M.S., BAETENS, D., MANDRIOTA, S.J., DI SANZA, C., OIKEMUS, S., LANE, T.F., SORIANO, J.V., MONTESANO, R. and IRUELA-ARISPE, M.L. (2000). Regulation of VEGF and VEGF receptor expression in the rodent mammary gland during pregnancy, lactation, and involution. Dev Dyn 218: 507-524.

PETERSEN, O.W. and POLYAK, K. (2010). Stem cells in the human breast. Cold Spring Harb Perspect Biol 2: a003160.

POCZOBUTT, J.M., TENTLER, J., LU, X., SCHEDIN, P.J. and GUTIERREZ-HARTMANN, A. (2010). Benign mammary epithelial cells enhance the transformed phenotype of human breast cancer cells. BMC Cancer 10: 373.

PONTIER, S.M. and MULLER, W.J. (2009). Integrins in mammary-stem-cell biology and breast-cancer progression--a role in cancer stem cells? J Cell Sci122: 207-14.

POSTOVIT, L.M., MARGARYAN, N.V., SEFTOR, E.A. and HENDRIX, M.J. (2008). Role of nodal signaling and the microenvironment underlying melanoma plasticity. Pigment cell \& melanoma research 21: 348-357.

PSAILA, B., KAPLAN, R.N., PORT, E.R. and LYDEN, D. (2006). Priming the 'soi' for breast cancer metastasis: the pre-metastatic niche. Breast Dis 26: 65-74.

QIU, Y., BEVAN, H., WEERAPERUMA, S., WRATTING, D., MURPHY, D., NEAL, C.R., BATES, D.O. and HARPER, S.J. (2008). Mammary alveolar development during lactation is inhibited by the endogenous antiangiogenic growth factor isoform, VEGF165b. Faseb J 22: 1104-1112.

QUARRIE, L.H., PITTS, J.D. and FINBOW, M.E. (1999). Interactions between normal mammary epithelial cells and mammary tumour cells in a model system. Cell Prolif 32: 351-361.

RADISKY, E.S. and RADISKY, D.C. (2010). Matrix metalloproteinase-induced epithelial-mesenchymal transition in breast cancer. J Mammary Gland Bio 
Neoplasia 15: 201-212.

REYNOLDS, A.R. (2009). Potential relevance of bell-shaped and u-shaped doseresponses for the therapeutic targeting of angiogenesis in cancer. Dose Response 8: 253-284.

RORTH, P. (2009). Collective cell migration. Annu Rev Cell Dev Biol 25: 407-429.

ROSSITER, H., BARRESI, C., GHANNADAN, M., GRUBER, F., MILDNER, M., FODINGER, D. and TSCHACHLER, E. (2007). Inactivation of VEGF in mammary gland epithelium severely compromises mammary gland development and function. Faseb J 21: 3994-4004.

SABE, H., HASHIMOTO, S., MORISHIGE, M., OGAWA, E., HASHIMOTO, A., NAM, J.M., MIURA, K., YANO, H. and ONODERA, Y. (2009). The EGFR-GEP100-Arf6AMAP1 signaling pathway specific to breast cancer invasion and metastasis. Traffic 10: 982-993.

SAKAKURA, T., NISHIZUKA, Y. and DAWE, C.J. (1976). Mesenchyme-dependent morphogenesis and epithelium-specific cytodifferentiation in mouse mammary gland. Science 194: 1439-1441.

SERRATI, S., MARGHERI, F., FIBBI, G., DI CARA, G., MINAFRA, L., PUCCIMINAFRA, I., LIOTTA, F., ANNUNZIATO, F., PUCCI, M. and DEL ROSSO, M. (2008). Endothelial cells and normal breast epithelial cells enhance invasion of breast carcinoma cells by CXCR-4-dependent up-regulation of urokinase-type plasminogen activator receptor (UPAR, CD87) expression. J Pathol214: 545-554.

SHIEH, A.C., ROZANSKY, H.A., HINZ, B. and SWARTZ, M.A. (2011). Tumor cell invasion is promoted by interstitial flow-induced matrix priming by stromal fibroblasts. Cancer Res 71: 790-800.

SICA, A., SCHIOPPA, T., MANTOVANI, A. and ALLAVENA, P. (2006). Tumourassociated macrophages are a distinct $\mathrm{M} 2$ polarised population promoting tumour progression: potential targets of anti-cancer therapy. Eur J Cancer 42: 717-727.

SLOAN, E.K., CIOCCA, D.R., POULIOT, N., NATOLI, A., RESTALL, C., HENDERSON, M.A., FANELLI, M.A., CUELLO-CARRION, F.D., GAGO, F.E. and ANDERSON, R.L. (2009). Stromal cell expression of caveolin-1 predicts outcome in breast cancer. Am J Pathol 174: 2035-2043.

STERNLICHT, M.D. (2006). Key stages in mammary gland development: the cues that regulate ductal branching morphogenesis. Breast Cancer Res 8: 201

SUBRAMANI, D. and ALAHARI, S.K. (2010). Integrin-mediated function of Rab GTPases in cancer progression. Mol Cancer 9: 312.

SUZUKI, M., MOSE, E.S., MONTEL, V. and TARIN, D. (2006). Dormant cancer cells retrieved from metastasis-free organs regain tumorigenic and metastatic potency. Am J Pathol 169: 673-681.

TABARIES, S., DONG, Z., ANNIS, M.G., OMEROGLU, A., PEPIN, F., OUELLET, V., RUSSO, C., HASSANAIN, M., METRAKOS, P., DIAZ, Z. et al. (2011). Claudin-2 is selectively enriched in and promotes the formation of breast cancer liver metastases through engagement of integrin complexes. Oncogene 30: 1318-1328.

TAN, W., ZHANG, W., STRASNER, A., GRIVENNIKOV, S., CHENG, J.Q., HOFFMAN, R.M. and KARIN, M. (2011a). Tumour-infiltrating regulatory T cells stimulate mammary cancer metastasis through RANKL-RANK signalling. Nature 470: 548-553.

TAN, J., BUACHE, E., CHENARD, M.-P., DALI-YOUCEF, N., RIO, M.-C. (2011b). Adipocyte is a non-trivial, dynamic partner of breast cancer cells. Int. J. Dev. Biol. 55: 851-859 (DOI: 10.1387/ijdb.113365jt).

TARIN, D. (2006). New insights into the pathogenesis of breast cancer metastasis. Breast Dis 26: 13-25.

THIERY, J.P., SASTRE-GARAU, X., VINCENT-SALOMON, B., SIGAL-ZAFRANI, X., PIERGA, J.Y., DECRAENE, C., MEYNIEL, J.P., GRAVIER, E., ASSELAIN, B., DE RYCKE, Y. et al. (2006). Challenges in the stratification of breast tumors for tailored therapies. Bull Cancer 93: E81-E89.

TOILLON, R.A., CHOPIN, V., JOUY, N., FAUQUETTE, W., BOILLY, B. and LE BOURHIS, X. (2002). Normal breast epithelial cells induce p53-dependent apoptosis and p53-independent cell cycle arrest of breast cancer cells. Breast Cancer Res Treat 71: 269-280.

TOULLEC, A., GERALD, D., DESPOUY, G., BOURACHOT, B., CARDON, M., LE-
FORT, S., RICHARDSON, M., RIGAILL, G., PARRINI, M.C., LUCCHESI, C. et al. (2010). Oxidative stress promotes myofibroblast differentiation and tumour spreading. EMBO Mol Med 2: 211-230.

TRIMBOLI, A.J., CANTEMIR-STONE, C.Z., LI, F., WALLACE, J.A., MERCHANT, A., CREASAP, N., THOMPSON, J.C., CASERTA, E., WANG, H., CHONG, J.L. et al. (2009). Pten in stromal fibroblasts suppresses mammary epithelial tumours. Nature 461: 1084-1091.

TRIMBOLI, A.J., FUKINO, K., DE BRUIN, A., WEI, G., SHEN, L., TANNER, S.M., CREASAP, N., ROSOL, T.J., ROBINSON, M.L., ENG, C. et al. (2008). Direct evidence for epithelial-mesenchymal transitions in breast cancer. Cancer Res 68: 937-945.

TSUJI, T., IBARAGI, S. and HU, G.F. (2009). Epithelial-mesenchymal transition and cell cooperativity in metastasis. Cancer Res 69: 7135-7139.

TURASHVILI, G., BOUCHAL, J., EHRMANN, J., FRIDMAN, E., SKARDA, J. and KOLAR, Z. (2007). Novel immunohistochemical markers for the differentiation of lobular and ductal invasive breast carcinomas. Biomed Pap Med Fac Univ Palacky Olomouc Czech Repub 151: 59-64.

VAKAET, L.A. and BOTERBERG, T. (2004). Pain control by ionizing radiation of bone metastasis. Int J Dev Biol 48: 599-606.

VALA, I.S., MARTINS, L.R., IMAIZUMI, N., NUNES, R.J., RINO, J., KUONEN, F., CARVALHO, L.M., RUEGG, C., GRILLO, I.M., BARATA, J.T. et al. (2010). Low Doses of lonizing Radiation Promote Tumor Growth and Metastasis by Enhancing Angiogenesis. PLoS One 5: -

VAUGHT, D., CHEN, J. and BRANTLEY-SIEDERS, D.M. (2009). Regulation of mammary gland branching morphogenesis by EphA2 receptor tyrosine kinase. Mol Biol Cell 20: 2572-2581.

WALLACE, A.E., GIBSON, D.A., SAUNDERS, P.T. and JABBOUR, H.N. (2010) Inflammatory events in endometrial adenocarcinoma. J Endocrinol 206: 141-157.

WALTER, M., LIANG, S., GHOSH, S., HORNSBY, P.J. and LI, R. (2009). Interleukin 6 secreted from adipose stromal cells promotes migration and invasion of breast cancer cells. Oncogene 28: 2745-2755.

WATSON, C.J. (2009). Immune cell regulators in mouse mammary development and involution. J Anim Sci 87: 35-42.

WIEDSWANG, G., BORGEN, E., KARESEN, R., QVIST, H., JANBU, J., KVALHEIM, G., NESLAND, J.M. and NAUME, B. (2004). Isolated tumor cells in bone marrow three years after diagnosis in disease-free breast cancer patients predict unfavorable clinical outcome. Clin Cancer Res 10: 5342-5348.

YAMASHITA, M., OGAWA, T., ZHANG, X., HANAMURA, N., KASHIKURA, Y., TAKAMURA, M., YONEDA, M. and SHIRAISHI, T. (2010). Role of stromal myofibroblasts in invasive breast cancer: stromal expression of alpha-smooth muscle actin correlates with worse clinical outcome. Breast Cancer.

YENIDUNYA, S., BAYRAK, R. and HALTAS, H. (2011). Predictive value of pathological and immunohistochemical parameters for axillary lymph node metastasis in breast carcinoma. Diagn Pathol 6: 18.

YU, Z., WILLMARTH, N.E., ZHOU, J., KATIYAR, S., WANG, M., LIU, Y., MCCUE P.A., QUONG, A.A., LISANTI, M.P. and PESTELL, R.G. (2010). microRNA 17/20 inhibits cellular invasion and tumor metastasis in breast cancer by heterotypic signaling. Proc Natl Acad Sci U S A 107: 8231-8236.

ZABUAWALA, T., TAFFANY, D.A., SHARMA, S.M., MERCHANT, A., ADAIR, B. SRINIVASAN, R., ROSOL, T.J., FERNANDEZ, S., HUANG, K., LEONE, G. et al. (2010). An ets2-driven transcriptional program in tumor-associated macrophages promotes tumor metastasis. Cancer Res 70: 1323-1333.

ZEISBERG, M. and NEILSON, E.G. (2009). Biomarkers for epithelial-mesenchymal transitions. J Clin Invest 119: 1429-1437.

ZHANG, N. and YANG, Q. (2009). Primary tumor resection may improve prognosis for nonoperable advanced breast cancer. Med Hypotheses 73: 1058-1059.

ZHAO, W., GRUBBS, C.J., MYERS, R.K. and NILSEN-HAMILTON, M. (2010). Parity is associated with an expanded macrophage population in the mammary gland. Int J Oncol 37: 1195-1202. 


\section{Further Related Reading, published previously in the Int. J. Dev. Biol.}

Cancer stem cells and angiogenesis

Yue Zhao, Qi Bao, Andrea Renner, Peter Camaj, Martin Eichhorn, Ivan Ischenko, Martin Angele, Axel Kleespies, Karl-Walter Jauch and Christiane Bruns

Int. J. Dev. Biol. (2011) 55: 477 - 482 (doi: 10.1387/ijdb.103225yz)

Casein kinase I epsilon somatic mutations found in breast cancer cause overgrowth in Drosophila Tomas Dolezal, Katerina Kucerova, Jana Neuhold and Peter J. Bryant

Int. J. Dev. Biol. (2010) 54: 1419-1424

Modeling and quantification of cancer cell invasion through collagen type I matrices

Olivier De Wever, An Hendrix, Astrid De Boeck, Wendy Westbroek,Geert Braems, Shahin Emami, Michèle Sabbah, Christian Gespach and Marc Bracke

Int. J. Dev. Biol. (2010) 54: 887-896

Epithelial-Mesenchymal Transitions in development and disease: old views and new perspectives

M. Angela Nieto

Int. J. Dev. Biol. (2009) 53: 1541-1547

Cadherin-mediated cell-cell adhesion and tissue segregation in relation to malignancy

Ramsey A. Foty and Malcolm S. Steinberg

Int. J. Dev. Biol. (2004) 48: 397-409

5 yr ISI Impact Factor $(2010)=2.961$

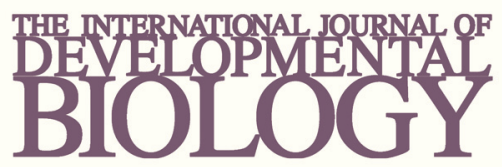

Volume 54 Nos. 6/7
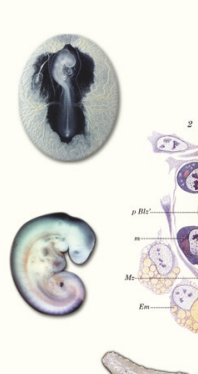

Developmental Hematopoiesis
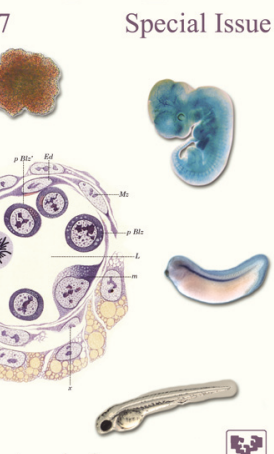

w

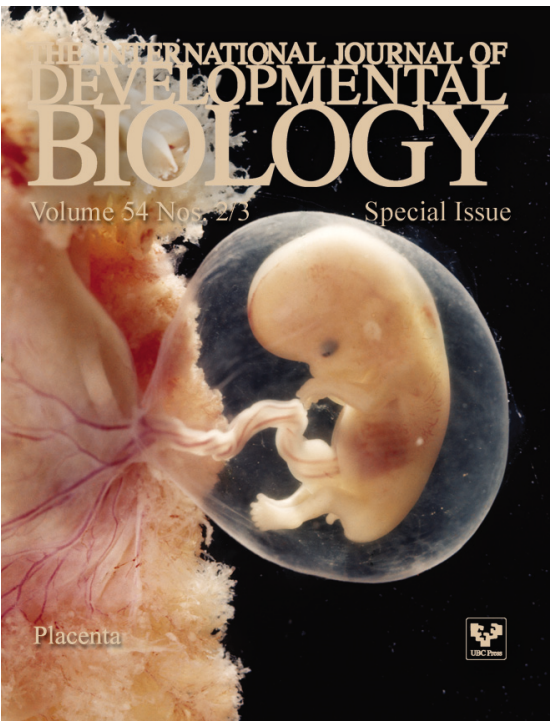

